\title{
Bakke as Precedent: Does Mr. Justice Powell Have a Theory?
}

\author{
Vincent Blasi $†$
}

What does it all mean? The Supreme Court's decision in Regents of the University of California v. Bakke invites assessment at many levels. Was it really a "Solomonic compromise" worthy of our constitutional tradition, as some prominent scholars have suggested?" Or does the decision represent, as I believe it does, a disturbing failure by the Court to discliarge its responsibility to give colierent, practical meaning to our most important constitutional ideals? Does the uncharacteristically opaque and simplistic opinion of Justice Stevens mask deep divisions and ambivalences among the four justices who subscribed to it? Can there be any validity to a conclusion like Justice Powell's that a state may make race-conscious decisions regarding university admissions in order to enrich its academic dialogue, but not to counteract the distributive injustices of three centuries? ${ }^{2}$ What does it say about the judicial process (or about academia) that the justices seem to liave profited so little from the unusually ricli scholarly literature on the subject of racial preferences? ${ }^{3}$ Who gets the better of the debate between Justice Stevens and Justices Brennan, White, Marshall, and Blackmun regarding whether interpretation of Title VI should be governed primarily by the "plain meaning" of its language or by the

$\dagger \quad$ Professor of Law, University of Michigan. B.A. 1964, Northwestern University; J.D. 1967, University of Chicago. I am indebted to Jesse Choper, Yale Kamisar, Paul Mishkin, Donald Regan, and Terrance Sandalow for their helpful comments on an earher draft.

1. Law professors who were quoted in the press as praising the Court's result imclude Alan Dershowitz ("an act of judicial statesmanship, a brilliant compromise"), Paul Freund ("a good thing"), A.E. Dick Howard ("a Solomonic compromise"), Benno Schmidt ("just about right"), and Charles Alan Wright ("a very civilized ruling"). See NewsweEk, July 10, 1978, at 20, 25; TiME, July 10, 1978, at 9.

2. $98 \mathrm{~S}$. Ct. at 2757-59. Apparently, Justice Powell would regard as illegitimate even a state legislature's decision to authorize race-conscious university admissions criteria in order to counteract perceived societal injustices unless the legislature made "findings of constitutional or statutory violations" relatimg to past racial discrimination. $98 \mathrm{~S}$. Ct. at 2758.

3. Of the many fine articles on the subject, those I have found most helpful are Boxill, The Morality of Preferential Hiring, 7 PhllosoPhy \& PUB. AFF. 246 (1978), Dworkin, Reverse Discrimination, reprinted in $\mathrm{R}$. DwORKIN, TAKING RIGHTS SERIOUSLy (1977); Ely, The Constitutionality of Reverse Racial Discrimination, 41 U. CH1. L. Rev. 723 (1974); Kaplan, Equal Justice in an Unequal World, 61 Nw. L. REv. 363 (1966); Nagel, Equal Treatment and Compensatory Discrimination, 2 Philosophy \& Pub. AFF. 348 (1973); and Sandalow, Racial Preferences in Higher Education: Political Responsibility and the Judicial Role, 42 U. CHI. L. REV. 653 (1975). 


\section{"unequivocally expressed legislative purpose?"4}

These and other questions beckon, but I want here to undertake a more mundane inquiry: to explore how the Court's decision in Bakke should be interpreted by judges and administrators who are obligated to adhere to it as a precedent. ${ }^{5}$ I an not concerned with what the Justices "really had im mind," only with the legal effect of what they said and did. ${ }^{6}$ At that level, what does it all inean?

The first step in such an inquiry inust be to deterinine which, if any, of the six opinions im Bakke states the governing legal principles that must guide officials. Five Justices voted to affirm those parts of the California Supreme Court's judgment which held that the Davis medical school's minority adınissions program was unlawful and which directed that Bakke be admitted to the school, but only four of these Justices could agree on the same reasons for affirmance. So only reasons or conclusions common ${ }^{7}$ to both the Stevens opinion, which was

4. $98 \mathrm{~S} . \mathrm{Ct}$. at $2768-79,2810-14$.

5. It is important to note that the obhigation of "adherence" may be different for an administrator (e.g., dean, admissions officer, or full faculty which makes admissions policy) than for a lower-court judge. For an administrator may, on the theory that a school is entitled to press its claims in court rather than forego them in anticipation of an adverse adjudication, act properly in adopting or supporting a special admissions program which he would hold to be illegal under Bakke were he a lower-court judge. In my opinion, however, administrators have some obligation to abide by precedent independent of the practical incentives they may have to avoid litigation or to prevail should litigation ensue. So even if their respective duties of adherence are different, judges and administrators need to have a view about the meaning of Bakke as a precedent. Throughout this Article, when I state a conclusion regarding what Bakke requires, I refer to what a lower-court judge should feel obligated to hold. The obligation of the administrator derives from this obligation of the lower-court judge, but need not be identical to it.

6. My whole scheme of analysis is based on the notion that a higher-court decision should be viewed as authoritative in some sense other than simply as data upon which one might rely in predicting whether subsequent lower-court decisions will be affirmed or reversed by the higher court. In other words, I believe a lower court should generally feel "bound" by the "decision" (which encompasses the dispositional decree and the objective meaning of the language of the opimion) of a higher court even in the face of developments, such as personnel changes or extrinsic evidence of either the true intentions of or changes of heart by key judges, which might radically alter the predictive calculus.

This is not to suggest that lower-court judges should decide their cases primarily by extrapolating from higher-court precedents. On the contrary, 1 think "vertical precedent" (i.e., decisions of a higher court) should confine the judgment of lower-court judges only by setting outer limits on the results they may reach; within those limits, lower-court judges should reason their way to results just as the higher court should, i.e., by looking to precedent for wisdom and continuity but not as a substitute for independent judgment regarding the merits of the competing claims. For an exposition and defense of a contrary view, see R. Dworkin, TAking Rights Seriously 124-26 (1977).

This or any other theory of precedent cannot be fully explained and defended within the confines of an article on a different subject, even when the article is premised on that theory of precedent. I sketch my view of precedent this much only to emphasize the point that my analysis of the Bakke decision should be of interest only to persons who hold a roughly similar view. Those who believe that a decision can have no "legal effect" apart from what the judges "really had in mind" should read no further.

7. By "common" I mean shared either as a matter of express endorsement or because the 
joined by Justices Stewart, Burger, and Rehnquist, and the Powell opinion, joined by no other Justice, can be said to have the authority of precedent with respect to this affirmance. Similarly, five Justices concluded that a portion of the Cahfornia Supreme Court's judgment which enjoined the medical school from "according any consideration to race in its admissions process" was properly before the Court and should be reversed. Again, only four Justices could agree on the same reasons for this conclusion; the fifth, Justice Powell, wrote only for himself. Only reasons or conclusions common to both the Powell opinion and that signed (and presuinably authored) jointly by Justices Brennan, White, Marshall, and Blackmun can be considered authoritative with respect to this reversal.

One is tempted to assume that since Justice Powell stands, in one sense, "in the middle," his opmion must have controlling significance on all questions. This is not necessarily so. While it is true that someone trying to predict how the Court would decide a subsequent case with different facts might with good reason regard Justice Powell as likely to be the crucial "swing vote," there are some readings of the Stevens opinion that would make it less restrictive, at least for certain types of race-conscious admissions programs, than the Powell opinion. On the other hand, there appears to be no reading of the Brennan ${ }^{8}$ opinion (or of Mr. Justice Blackmun's separate opinion explaining his joining of the Brennan opmion) that would inake it more restrictive than the Powell opmion; any special admissions prograin that passes muster under Justice Powell's standard can be deemed to quahify for approval under the standards adopted by a majority of the Court. ${ }^{9}$

conclusion is a necessary element or lesser included consequence of the position adopted. Thus, a Justice who believes that defamatory communications are absolutely protected under the first amendment shares "in common" with his brethren who subscribe to the New York Times $v$. Sullivan "reckless disregard" standard the view that damages cannot be awarded to public offcials for defamatory coinmunications which are not published with either knowledge of their falsity or in reckless disregard of the truth. See New York Times v. Sullivan, 376 U.S. 254 (1964).

8. For convenience, I refer to the opinion signed jointly by Justices Brennan, White, Marshall, and Blackmun as "the Brennan opinion," even though there is no reason to suppose that Justice Brennan had a dominant role in its formulation. The Justices who signed the opmion are listed in order of seniority.

9. There are passages in the Brennan opinion which might be read to suggest that a special admissions program could be hypothesized that would stand a poorer chance of passing muster under the Brennan analysis than under that employed by Justice Powell. For example, the Brennan opinion rests mainly on the proposition that race may be taken into account in the admissions process in order to coinpensate for the disadvantages blacks suffer as a result of pervasive past discrimmation. If at some future time the lingering effects of past discrimination were thought to have largely dissipated, the Powell rationale based on the educational benefits of diversity would provide stronger support for race-consciousness than the Breunan analysis. See $98 \mathrm{~S}$. Ct. at 2767 n.l. More significantly, a progrant which, unlike that at Davis, gave preference to all blacks without regard to their family incomes or the quahty of their past educational opportunities might be justified more easily under the Powell rationale. In addition, the Brennan opinion expresses slightly more concern about the possibility that a race-conscious admissions program might stig- 
Thus, a person seeking only to understand the force of Bakke as a precedent should concentrate exclusively on the Stevens and Powell opinions.

\section{The STEvens Opinion}

The first thing to notice about the Stevens opinion is that it addresses only Bakke's statutory contention. The opinion says or implies nothing about whether the Davis inedical school's or any other admis- sions prograin violates the equal protection clause of the fourteenth ainendment. Thus, the adinissions practices of an educational institution, department, or prograin which does not qualify under the terms of Title VI as a "prograin or activity receiving Federal financial assistance" are governed by the Bakke precedent only to the extent that the five Justices who did address the constitutional issue in the case-Justices Powell, Brennan, White, Marshall, and Blackınun-can be said to agree ${ }^{10}$ on the same constitutional conclusions and, then only if those adinissions practices amount to "state action." Specifically, a lower-court judge or an adinissions officer would not act in violation of the Bakke precedent in approving the use by a private or state-supported school or unit not covered by Title VI of a system of racial preferences identical to that einployed by the Davis medical school. The Stevens opinion, and the votes of the four Justices who subscribed to it, would have no authority in such a case. Moreover, even if one wanted to use the Bakke precedent not as authority in the strict sense, but as an aid in predicting how the Justices would decide future cases, there is no reason to suppose that all of the adherents to the Stevens opinion would read the equal protection clause of the Constitution to prohibit everything prohibited by their reading of Title VI's more specific language. Three of the four Justices who subscribed to the Stevens opimion, it should be noted, have at least once in the past found no constitutional infirmity in a race-conscious statute without basing their analysis on the special niterest a state inight have in considering race in order to fashion a reinedy for past racial discrimination. ${ }^{11}$

matize the intended beneficiaries; it is conceivable that an unusually "stigmatic" system would be struck down more readily by the Justices who joined the Brennan opinion than by Justice Powell. All of these possibilities, however, are so dependent on inchoate aspects of its analysis, that the Brennan opinion should not be viewed as restrictive, in the sense of binding lower-court judges, on the basis of these speculations.

10. See note 7 supra.

11. In Umited Jewish Organizations, Inc. v. Carey, 430 U.S. 144 (1977), Justices Rehnquist and Stevens joined that part of Justice White's opinion which affirmed a state's power, independent of any duties and powers created by the federal Voting Rights Act, to take race into account in devising a reapportionment plan. In the same case, Justice Stewart wrote an opinion explicitly rejecting the contention that "racial awareness in legislative apportionment is unconstitutional per 
Thus, educational institutions and programs not covered by Title VI lawfully may proceed, insofar as the Bakke decision is concerned, with whatever admissions programs they think best serve their purposes, subject only to the quahification that the rare program that would run afoul of both the Powell and Brennan opinions may not be instituted. But many, if not inost, educational institutions and programs do receive federal financial assistance. ${ }^{12}$ Programs and institutions in this category are constramed by the Bakke precedent to the extent that the Stevens and Powell opinions agree on what Title VI prohibits. ${ }^{13}$ It becomes necessary, therefore, to discern the meaning of the Stevens opinion. This, as we shall see, is no easy task.

Justice Stevens begms his opinion by arguing that "the question whether race can ever be used as a factor in an admissions decision is not an issue in this case." "[D]iscussion of that issue," he states, "is inappropriate." 14 To support this contention, Stevens takes pams to demonstrate that the paragraph in the trial court's order enjoining the university "from considering plamtiff's race or the race of any other applicant in passing upon his application for admission" was not prop-

se"; nothing in the opinion indicates that Stewart meant to confine his approval of such racial awareness to the remedial context. Thus, while the New York legislature might have drawn up its race-conscious reapportionment plan in order to redress past racial discrimination (or, more precisely, to satisfy federal officials concerned about such discrimination), the rationales adopted in United Jewish Organizations by Justices Stewart, Rehnquist, and Stevens would seem to apply to all race-conscious reapportionment, nonremedial as well as remedial.

12. On the scope of coverage of Title VI, see Board of Pub. Instruction v. Finch, 414 F.2d 1068 (5th Cir. 1969); Stewart v. New York Univ., 430 F. Supp. 1305 (S.D.N.Y. 1976); Mandel v. United States, 411 F. Supp. 542 (D. Md. 1976); Bob Jones Univ. v. Johnson, 396 F. Supp. 597 (D.S.C. 1974); McLeod v. College of Artesia, 312 F. Supp. 498 (D.N.M. 1970).

13. I do not think a lower court would be justified in according no authoritative significance to the interpretation of Title VI contained in the Stevens opinion on the ground that its interınediate preinise-that Title VI prohibits some instances of race-conscious state decisionmaking that might be permissible under the fourteenth anendment-has now been rejected by a majority of the Court (the five other justices in Bakke who found the substantive standards of Title VI to be coextensive with those of the fourteenth amendinent). In my view of precedent, it is the conclusions of the higher court, not the intermediate steps in its reasoning, that should define the limits which bind lower courts. Were it otherwise, lower courts would have too much leeway, as I see it, to discredit the precedent of a higher court by pointing to subsequent opinions which reject one or more propositions that were essential steps in the reasoning behind the precedent. Judicial results, however rationalized, typically have an intuitive vitality that einbodies much of what it is that leads us to value precedent in the first place. Cf. Prudential Ins. Co. v. Benjainin, 326 U.S. 408, 424 (1946). Until tensions in the edifice of rationalization force the higher court to express severe doubt about a result it has reaclied earlier, I think lower courts should treat that result as authoritative unless the holding is of unusually ancient vintage, or was so unexamined as to have been virtually inadvertent, or for some other reason is not deserving of the respect normally accorded precedent. Thus, with regard to the Bakke decision, the fact that five Justices thought that admissions programs that einploy fixed quotas violate the dictates of Title VI amounts to a collective judgment which lower courts inust respect. The fact that these five Justices reached this conclusion by varying routes, endorsing different intermediate premises, is to me immaterial. This problem does illustrate, however, the degree to which my understanding of the Bakke precedent rests on a view of precedent that inany readers may not share.

14. $98 \mathrm{~S}$. Ct. at 2810 . 
erly before the United States Supreme Court because the California Supreme Court had held that if, as it believed, the particular admissions program used by the Davis medical school was unlawful, Bakke should be admitted to study without the need for further consideration of his application. As Stevens puts it, "[t] he order did not include any broad prohibition agamst any use of race in the admissions process; its terms were clearly limited to the University's considcration of Bakke's application. Because the University has simce been ordered to adinit Bakke, paragraph 2 of the trial court's order no longer has any significance." 15

Why did Stevens engage in this highly technical, rather strained effort to narrow the scope of the case? Two explanations seem plausible. One is that he was disturbed at his brothers Powell, Brennan, White, Marshall, and Blackmun for treating the case as though it permitted a decree, not simply dicta, approving some consideration of race in passing upon applications for admission. The Cahfornia Supreme Court's judgment for Bakke was "affirmed im part and reversed in part." Members of the public not versed in the ways of courts could be expected to view such a disposition as more of a "tie" or "standoff" than if the judgment for Bakke had been affirmed in toto, even with limiting dicta approving some consideration of race im the admissions process. A mixed decree, by this reasoning, would more effectively inute outcry by minority groups over Bakke's personal victory and reduce anxieties that might otherwise have been generated by the demise of the Davis program. If Justice Powell and the Brennan group broadened their view of the issues still present in the case in order to fashion the decree in this manner and thereby achieve this political effect, Justice Stevens might properly protest. In this view, Stevens could believe that Title VI does indeed mandate a "colorblind" standard for admissions and he could be willing to argue the merits of this position with the other justices. He simply would be objecting to the fact that Justice Powell and the Brennan group treated as "an issue in this case," justifying a decree directed to the point, the question whether race can be taken into account in some manner less objectionable than by means of the Davis quota system.

The second explanation is that Stevens did not want to address in any way the question whether Title VI might permit some consideration of race because he believed that the Davis program, with its explicit racial quota, ran afoul of the specific language of Title VI for special reasons not applicable to more flexible race-conscious admissions procedures.

It is of considerable importance which of these two explanations is

15. Id. at $2809-10$ (emphasis in original). 
adopted because if, as under the second interpretation, the Stevens opinion is read as having little or no relevance to other types of raceconscious programs, it is possible that one of its adherents, when forced to rule upon such a program, might apply a standard more permissive than that adopted by Justice Powell. This mere possibility-it needn't be a probability-would mean that the Powell opmion is not necessarily pivotal, and hence is not truly authoritative in the sense that officials should feel bound by its standards, in cases involving admissions procedures that do not fall within the scope of Justice Stevens' narrow rationale for invalidating the Davis program.

At first blusl, the second interpretation (objection to other Justices even talking about the validity of other kinds of race-conscious programs) seems more plausible given Stevens' statement that "discussion of [not just a decree relating to] that issue is inappropriate." ${ }^{16}$ However, if Justice Stevens' rationale for invalidating the Davis program is best understood as embodying a colorblind standard for Title VI, the first interpretation (objection to the mixed decree) would seem to be more plausible. For it would be the height of impudence to chastise other justices for simply addressing the question whether race can ever be considered in an admissions program when one's own rationale for resolving the case necessarily addresses and answers that question. ${ }^{17}$ Thus, $m$ order to decide which of the two interpretations of the Stevens opinion should be adopted, and consequently whether the Powell opinion should be considered authoritative, one must scrutinize Justice Stevens' analysis to determine whether or not it rests on the proposition that Title VI mandates complete indifference to race in the admissions process. ${ }^{18}$

Justice Stevens' discussion of the merits begms by quoting in full the language of section 601 of the Civil Rights Act of 1964, the statutory provision at issue:

No person in the United States shall, on the ground of race, color, or national origin, be excluded from participation in, be denied the bene-

16. Id. at 2810. (emphasis added).

17. Conceivably, Justice Stevens could defend this course by arguing that while it was necessary for him to address the question whether race can ever be taken into account because his reading of Title VI (the colorblind standard) would by its logic control many programs not before the Court, no such logic compelled the Justices who read Title VI to einbody a more flexible standard to discuss cases not before the Court. However, the judicial practice of discussing for illustrative purposes cases "on the other side of the line" is so well established and enlightening that Justice Stevens should not be read to claim that the difference in their respective positions gives him but not his brethren warrant to discuss the broader imphications of one's analysis.

18. This inquiry is necessary, I believe, even if the most satisfying behavioral explanation for the Stevens opinion is that it was designed to be ambiguous in order to enhist the adherence of Justices with widely differing views. For in a legal system which embodies the idea of precedent, and which derives legitimacy in part from that fact, judges simply cannot be permitted to decide cases without having to endure the precedential consequences of their decisions. Doctrinal coherence inust be imputed even when not intended. 
fits of, or be subjected to discrimination under any program or activity receiving federal financial assistance.

The opinion then offers a deceptively simplistic syllogism:

The University, through its special admissions policy, excluded Bakke froin participation in its program of medical education because of his race. The University also acknowledges that it was, and still is, receiving federal financial assistance. The plain language of the statute therefore requires affirmance of the judgment below. ${ }^{19}$

And then a caveat:

A different result cannot be justified unless that language misstates the actual intent of the Congress that enacted the statute or the statute is not enforceable in a private action. Neither conclusion is warranted. ${ }^{20}$

The rest of the opinion attempts to demonstrate tliat "nothing in the legislative history justifies the conclusion that the broad language of section 601 sliould not be given its natural meaning,"21 and that the section was meant to generate private causes of action.

But what is this "natural meaning" of section 601 that Stevens treats as obvious? Surely the words "on the ground of race . . . be subjected to discrimination" do not mexorably mandate a "colorblind" standard. In fact, some opponents of section 601 expressed concern that the antidiscrimination clause of the statute might be read to prohibit federally funded programs which fail to employ racial preferences m order to redress racial imbalance. ${ }^{22}$ Was it the phrase "be excluded from participation in" that led Justice Stevens to consider the Davis program plainly imconsistent with the language of Title VI? One can argue forever about what should properly be considered "discrimination"-in legal circles, the term normally is used to mean "consideration of a trait in an illegitimate way," which still requires a judgment about when consideration of the trait really is illegitimate-but a prohibition of exclusion "on the ground of" a named trait might be thought to answer unequivocally in the negative the question whether the trait can ever be taken into account. It miglit be significant in this regard that while Bakke could plausibly be described either as having been "excluded from participation" or as having been "subjected to discrimination," at several places in the opinion Justice Stevens carefully confines his analysis of section 601 to the "ban on exclusion."

However, even if the key to understanding Stevens is the significance he attaches to the statutory language prohibiting "exclusion from participation in" federally funded programs "on the ground of race," it is not clear that the significance of this language is that it mandates a colorblind admissions process. Instead, the ban on "exclusion from"

19. $98 \mathrm{~S} . \mathrm{Ct}$. at 2811.

20. Id.

21. Id. at 2814 .

22. Id. at 2812 . 
may be thought to have special implications for a rigid, formal quota system like that employed at Davis, for under such a system majorityrace applicants are totally "excluded from participation" in the competition for some places in the class, not simply disadvantaged in that competition as in other admissions programs which employ racial preferences in a more flexible manner.

I do not think the Stevens opimon should be read this narrowly. Under Title VI, the relevant unit from which a person is not to be excluded would seem to be the "program or activity" itself, not any one fungible place in the program. A majority-race applicant who can only coinpete for 84 places in a program while his minority-race competitors can try for 100 places should certainly be considered "disadvantaged" because of his race, but not totally "excluded." The more sensible explanation for Justice Stevens' emphasis on the exclusion clause is that exclusion is the concept applicable to an admissions decision-the applicant is either let in or kept out-whereas discrimination relates to how a person is treated within a prograni. Thus, the Stevens opinion probably should be read to disapprove on Title VI grounds at least some race-conscious admissions procedures that do not employ rigid quotas.

There still remains the iniportant question whether the Stevens opinion interprets Title VI to mandate a completely colorblind standard, or whether there might be some consideration of race that would not, under the Stevens rationale, amount to exclusion froin participation "on the ground of" race. It might be argued that "exclusion on the ground of" implies a prohibition similar to that usually associated with a ban on "discrimination"- - a mandate that race not be given too much weight, or not considered when it is logically irrelevant im the strictest sense. In this regard, it may be significant that although Justice Stevens is careful to define the issue before the Court as the meaning of the exclusion clause of section 601, at two places in the opinion he alludes to the "statutory prohibition agamst discrimination" as though it were a generic policy that reveals the meaning of the exclusion clause. One iniglit also ponder Justice Stevens' choice of a peroration for his discussion of the main issue: "As succintly phrased during the Senate debate, under Title VI it is not "permissible to say "yes" to one person, but to say "no" to another person, only because of the color of his skin." "23 Only because? What if partly because? Is this an imprecise way of saying that race cannot be a "dominant" factor, or perhaps not the only nonquantitative factor, but that it can tip the balance in margimal cases?

Against this reading of the opinion is the fact that Justice Stevens

23. Id. at 2814 . 
at one point states that "the proponents of Title VI assumed that the Constitution itself required a colorblind standard on the part of government." 24 While he then argues that the statute was not designed merely as "a constitutional appendage," Stevens also notes that "[t]he Act's proponents plainly considered Title VI consistent with their view of the Constitution ...."25 Moreover, if im fact Justice Stevens thought that the exclusion clause of section 601 proscribes only certain kinds of race-conscious decisions - those which give race "inappropriate" weight-he should have felt obliged to say more about the specifics of the statutory standard than the following: "the meaning of the Title VI ban on exclusion is crystal clear: Race cannot be the basis of excluding anyone from participation in a federally funded program."26 Finally, the fact that Stevens sometimes refers to "racial discrimination" as though it were the same as "exclusion on the ground of" race may simply mean that he also considers any ban on racial "discriunination" to imply a colorblind standard, a position that is arguable if not compelling.

I believe, therefore, that the Stevens opinion should be read to adopt a colorblind standard: any explicit consideration of race in the adimssions process, even as a inarginal factor, violates Title VI. Consequently, the first interpretation of the opinion is the unore plausible one: Justice Stevens' opening argument that the Court did not have before it the issue whether race can ever be considered should be read as a criticism of the other Justices for handing down a mixed decree, reversing in part the California Supreine Court, not as an admonition that one's views on that issue are not relevant in evaluating the Davis program because of its peculiar features.

Thus, I conclude that for educational prograins covered by Title VI, any race-conscious adunissions process violates the standard adopted in the Stevens opinion. Any such process that also violates the standards laid down by Justice Powell in his separate opinion then runs afoul of the standards endorsed by five Justices, a majority of the Court, and hence should be considered unlawful. The Powell opinion is, after all, the key to assessing the precedential significance of the Bakke decision.

II

\section{The Powell OpINION}

Justice Powell voted to affirm that part of the California Supreme Court's judgment which held the Davis medical school's admissions

\footnotetext{
24. Id. at 2812-13.

25. Id at 2813 .

26. Id. at 2813-14.
} 
program unlawful under Title VI and the fourteenth amendment and which directed that Bakke be admitted to study at the school. He voted to reverse that portion of the judgment below which enjoined the school from according any consideration to race in its admissions process. To justify these contrasting results, Powell invoked a subtle distinction between different types of race-conscious admissions programs, a distinction he sought to explicate by means of specific examples as well as general formulations. Despite his efforts, Justice Powell's distinction is likely to prove elusive to many officials who will have to apply it. To understand the controlling standard that emerges from his opinion, it is first necessary to appreciate the reasoning that carried Powell to the results he reached.

The logic of the Powell opinion can be summed up in the following conclusions:

(1) "Title VI inust be held to proscribe only those racial classifications that would violate the Equal Protection Clause of the Fourteenth Amendment."27

(2) Under the fourteenth ainendment, "[r]acial and ethnic distinctions of any sort are inherently suspect and thus call for the inost exacting judicial exammation."28

(3) The use of racial classifications in the context of school desegregation and employment discrimination is less suspect because such use is for the purpose of remedying past constitutional or statutory violations rather than determining imitial rights, and also because meinbers of nonminority races typically are not injured by such use as severely as are persons whose applications for admission to educational institutions are rejected on the basis of race. ${ }^{29}$

(4) "Preferring members of any one group for no reason other than race or ethnic origin," in other words treating racial diversity or proportionality as an end in itself, is a "facially invalid" governmental purpose which cannot serve to justify a special admissions program. ${ }^{30}$

(5) "[I]n the absence of judicial, legislative, or administrative findings of constitutional or statutory violations," it is inpermissible for a state institution to design an admissions process to aid "persons perceived as neinbers of relatively victimized groups at the expense of other innocent individuals" because "[w]ithout sucl findings of constitutional or statutory violations, it cannot be said that the government has any greater interest in helping one individual than in refraining froin harming another." 31

27. Id. at 2747.

28. Id. at 2749 .

29. Id at 2754-56.

30. Id. at 2757.

31. Id. at 2757-58. 
(6) The University of California "does not purport to have made, and is in no position to make, such findings [of constitutional or statutory violations]" because "isolated segments of our vast governmental structures are not competent to make those decisions, at least in the absence of legislative mandates and legislatively determined criteria." 32

(7) The purpose of "improving the delivery of health care services to communities currently underserved" can be assumed in some circumstances to be "sufficiently compelling to support the use of a suspect classification" but the University "has not carried its burden of demonstrating that it must prefer members of particular ethnic groups over all other individuals in order to promote better health care delivery to deprived citizens." 33

(8) A state university lias a compelling interest, sufficient to justify consideration of race or ethnic background in its admissions process, in seeking a diverse student body in order to foster an "atmosphere of 'speculation, experiment and creation," and lience "must be accorded the riglit to select those students who will contribute the most to the "robust excliange of ideas." "However, "the state interest that would justify consideration of race or ethnic background . . . is not an interest in simple ethnic diversity, $m$ which a specified percentage of the student body is in effect guaranteed to be members of selected ethnic groups, with the remaining percentage an undifferentiated aggregation of students." Ratlier, "[t]lie diversity that furthers a compelling state interest encompasses a far broader array of qualifications and characteristics of which racial or ethnic origin is but a smgle though important element." 34

(9) The Davis medical school's "special admissions program, focused solely on ethnic diversity, would limder rather than further attainment of genuine diversity," and thus cannot be justified on the basis of the interest in liaving a diverse student body in order to enrich the academic environment. ${ }^{35}$

(10) "In enjoimmg petitioner from ever considering the race of any applicant, however, the courts below failed to recognize that the state has a substantial interest that legitimately may be served by a properly devised admissions program involving the competitive consideration of race and ethnic origm." 36

Some of these conclusions, particularly number five, are difficult to defend. The present task, lowever, is not to criticize but to interpret. What does the Powell logic imply for race-conscious admissions pro-

32. Id. at $2758-59$.

33. Id. at 2759.

34. Id. at $2760-61$.

35. Id. at 2761 (emphasis in original).

36. Id. at 2764 . 
grams that are slightly or greatly different from that employed by the medical school at Davis?

The key feature of Justice Powell's analysis is the proposition that racial preferences may lawfully be employed in order to enrich the academic environment by selecting a heterogeneous student body, but only if the consideration of race forms merely one part of an adinissions program that "is flexible enough to consider all pertinent elements of diversity im hight of the particular qualifications of each applicant." ${ }^{37}$ The Davis program did not qualify under this standard because it "focused solely on ethnic diversity." On the other hand, the Harvard undergraduate admissions program, says Powell, represents an "illuminating example" of a permissible consideration of race because it "treats each applicant as an individual in the admissions process." Several factors differentiate the Davis and Harvard programs. The task for one who would assess the precedential significance of the Powell opinion is to figure out which of these factors is determmative.

Two differences between the Davis and Harvard programs were mentioned by Justice Powell. First, accordmg to Powell, the nonquantitative aspects of the Davis program "focused solely on ethnic diversity," whereas the Harvard program gave weight to several considerations, anong them race, musical talent, athletic ability, geographic background, and "a hife spent on a farm." Second, Davis employed a track systein which "insulate[d] each category of applicants with certam desired qualifications from competition with all other applicants." 38 Under the Harvard procedure, in contrast,

[t]he applicant who loses out on the last available seat to another candidate receiving a "plus" on the basis of ethnic background will not have been foreclosed from all consideration for that seat simply because he was not of the right color or had the wrong surname. It would mean only that his combined qualifications, which may have included similar nonobjective factors, did not outweigh those of the other applicant. His qualifications would have been weighed fairly and competitively, and he would have no basis to complain of unequal treatinent under the Fourteentli Amendment. ${ }^{39}$

So it appears that under the Powell opinion two relevant criteria in determining the permissibility of a race-conscious admissions program are the number of traits that are given special weight and the degree to which those traits are considered im a competitive fashion. The opinion does not make clear, however, just how these criteria relate to each other and exactly how they are to be ineasured.

Suppose, for example, that an admissions program were to give

37. Id. at 2763 .

38. Id. at 2762 .

39. Id. at 2763 . 
special weight to five factors (race, sex, family incoine, age, and geographic background) and were to provide that traits relating to these factors that are soinetimes in short supply under purely quantitative, grade-predictive adinissions standards inust be represented to a substantial extent-say, that in each entering class there inust be at least $15 \%$ blacks, women, persons froin families earning less than $\$ 15,000$ per annum, persons over twenty-eight years of age, and persons who have spent more than half their lives residing at least 500 miles from the place where the school is located. The Powell opinion probably should be read to disapprove such a program, for at one point the opinion states "[n]or would the state interest in genuine diversity be served by expanding petitioner's two-track systein into a multi-track program with a prescribed nuinber of seats set aside for each identifiable category of applicants." 40 On the other hand, the context in which this statement appears might suggest that the reference to a "inultitrack" prograin was ineant to denote a process in which each of several ethnic groups is given its own quota (e.g., 10\% blacks, 5\% Chicanos, 5\% Orientals, 5\%.Italian-Americans) rather than one in which factors unrelated to ethnic background are selected for on a percentage basis. The question is not wholly free froin doubt.

Conversely, suppose an admissions program were to give weight to only one nonquantitative factor, race, but were to do so in a flexible inanner-for example, by providing that whenever the statistically predicted grade-point average of two coinpeting applicants differs by no more than .2 and when the predictive power of the statistical fornula is such that there is no greater likelihood than .6 that the applicant with the higher predicted GPA will in fact outperform his rival, race may be given controlling weight in choosing between the two applicants. At first glance, this kind of prograin would seem to be impermissible under the Powell opinion because it would not be "flexible enough to consider all pertinent elements of diversity in light of the particular qualifications of each applicant." 41 Nonetheless, such a program would not "insulate the individual from comparison with all other candidates,"42 and certainly would not ainount to "the functional equivalent of a quota system." ${ }^{\text {"33 }}$ So one really cannot be certain how Justice Powell would rule on an adinissions process that employed a racial preference in this inanner.

To determine how these and other admissions programs should fare under the Bakke precedent, it is necessary to develop tnore of a rationale for the Powell standard than the Justice himself provides. His

40. Id. at 2762 .

41. Id. at 2763.

42. Id. at 2762.

43. Id. 
fragmentary examples and allusions to criteria do not give sufficient guidance standing alone, and they are not adequately linked in the opinion with the more general discussion of the compelhng interest in academic diversity to enable one to discern how the Powell standard would operate im a wide range of test cases. More of a theoretical base is needed to decide such important questions as whether any program can be upheld that does not employ both a multitude of factors and competitive consideration thereof; whether either of these features weighs more heavily than the other; whether a sliding scale is to be employed (the more and better the nonquantitative factors considered the less "competitive" need be the consideration of them, and vice versa); whether the nonquantitative factors to be considered must be formalized (aimounced and defined in advance or given a fixed weight); what really anounts to "competitive consideration"; and whether any other features besides the number of factors and competitive consideration of them are relevant in assessing the vahitity of an admissions prograin.

In seeking to determine the theoretical basis for the Powell analysis, it is useful to begin by asking what basic values might lead one to perceive a difference between admissions programs that consider in a formal way only one nonquantitative trait and those that consider several traits, and between programs that einploy fixed quotas and those that provide for "competitive consideration" of all applicants. More specifically, of course, one should ask what basic values might lead a person to consider the Harvard undergraduate admissions program permissible and the Davis medical school program impermissible. These inquiries, it should be noted, are more focused and more difficult than the effort to determine what basic values led Justice Powell to consider all race-conscious decisionmaking disfavored and hence suspect.

Three fundamental values seem inost likely to underlie the distinctions that Justice Powell found controlling. One is the value of strict rationahity, soinetimes referred to in constitutional adjudication as the means-end relationship or the need for a "close fit." If the disfavored means of race-conscious decisionmaking is to be justified by the end of educational diversity, then there inust be good reason to believe that the particular variant of the means employed is both highly productive of the end and superior in this regard to other means (or variants) that are less disfavored. Second, apart froin the relationship between means and ends, some race-conscious admissions programs might be superior to others because they better respect the individual dignity of the applicants. Finally, whenever race is a factor in decisionmaking, there is a risk that the social goal of the reduction of racial prejudice in all spheres, private as well as public, will be undercut. The pursuit of this goal can be considered a fundainental value in our society, and race- 
conscious admissions programs may differ with respect to whether, and how much, they undercut or jeopardize this value.

In deciding which of these values should figure most prominently in rationalizing the Powell opinion, one should not give much weight to the fact that the "strict rationality" and "reduction-of-prejudice" values seein society-oriented while the dignity value is individual-oriented. It is true that Justice Powell repeatedly refers to the "individual rights" of applicants. However, in our constitutional system individuals who establish the requisite threshold of personal injury have "individual" rights not only to be treated in certain ways as persons but also not to be disadvantaged im certain ways unless social interests of sufficient magnitude are thereby served. As Powell himself expresses it in Bakke, "when a State's distribution of benefits or imposition of burdens hinges on the color of a person's skin or ancestry, that individual is entitled to a demonstration that the challenged classification is necessary to pronote a substantial state interest." 44

\section{A. Strict Rationality}

There is fragmentary evidence in Justice Powell's opinion to indicate that the value of strict rationality really is the key to his analysis. The passage just quoted, which appears at the summing-up stage of the opinion, suggests as inuch. So too does Justice Powell's introduction to the critical section of his opinion in which he compares the Davis and Harvard systerns: "As the interest of diversity is compelling im the context of a university's admissions program, the question remains whether the program's racial classification is necessary to promote this interest."45 But if this value of strict rationality explains the difference between Davis and Harvard, between single- and multiple-trait preferences, and between quotas and "coinpetitive consideration," Justice Powell leaves many steps in the analysis to be filled in. How might an admissions process of the sort approved by Powell be thought to serve the end of educational diversity more rationally than the Davis program and other systems implicitly disapproved by the Justice?

One element of rationality is economy. But of the various admissions systems that might be adopted im pursuit of the goal of diversity, the single-trait quota systein must be viewed as annong the most economical in terms of the resources required to administer it. It is untenable, therefore, to regard the factor of economy as forming any part of the basis for Justice Powell's distinctions. On the other hand, the fact that a single-trait quota system is economical should not be thought to undercut the proposition that the Powell opinion may be based on the

44. Id. at 2764.

45. Id. at 2761 . 
value of strict rationality. For under traditional analysis, and there is no reason to suppose that Justice Powell intended to depart from tradition in this respect, a decisionmaking process that takes a sensitive trait such as race into account in a certain way cannot be upheld unless there is reason to believe that the precise manner in which the trait is considered is highly productive of (closely fitted to) the goal that would justify such consideration of the trait, not simply cheaper than alternatives that are otherwise more productive of the goal. ${ }^{46}$ Consequently, one must inquire whether there are other elements of rationality that provide a basis for challenging single-trait systems, or quota systems, or systems that combine these two features.

One such element may be maximization of the traditional educational skills of the students who are admitted under botlı the special and regular admissions programs. For if the ultinate goal is a stimulating educational environment characterized by a "robust exchange of ideas," the skills that are measured by traditional quantitative indicators (knowledge and aptitude) are highly relevant in assessing an applicant's likely contribution to the goal even if not the only variables that ought to be considered. In this regard, "diversity" in the narrow sense of formal heterogeneity cannot be considered valuable for its own sake. The ultimate measure of educational diversity must be an educational product of soine sort-intellectually productive differences of opinion, for example, or richer sources of information. And one variable that inevitably bears on the quality of the educational product is the knowledge and analytical aptitude of the student body. Tlius, an admissions program that is imdifferent to this variable cannot be pursuing the goal of educational diversity in a strictly rational fashion.

How do single-trait systems and quota systems fare in terms of this element of rationality? A special admissions program that considers only one trait might be thouglit to be irrational in that it needlessly limits the size of the pool of persons eligible for consideration under the program, with the virtually certaim result that the special admittees will be less able in terms of traditional academic skills than if the pool liad been larger. If a scliool relies heavily on traditional quantitative credentials in choosing whicl of the special applicants to admit, it stands to reason that the overall quantitative credentials of the special admittees will increase as the school lias inore eligible special applicants from whicli to choose. This argument has force, however, only if the number of places in the class to be filled by special adinittees is fixed. For if the number of available places were to increase in proportion to the increase in the number of eligible applicants, there is no reason to sup-

46. See, e.g., Califano v. Goldfarb, 430 U.S. 199, 205 (1977); Craig v. Boren, 429 U.S. 190, 198 (1976); Frontiero v. Richardson, 411 U.S. 677,690 (1973); Stanley v. Illinois, 405 U.S. 645, 659 (1972) ('[T]he Constitution recognizes higher values than speed and efficiency."). 
pose (other things being equal) that the quantitative credentials of those admitted under the special program would be higher than under a program with fewer applicants but also fewer places. And Justice Powell inakes no reference at all to this factor of the percentage of places in the class encompassed by the special admissions program; his opimion reads as though the particular problem presented by a singletrait prograin can be solved by expanding the program to consider more traits even if a proportionately larger segment of the class thereby consists of persons adınitted under the special program. If so, the possible effect on the quantitative credentials of the special admittees cannot be a basis for Justice Powell's distinction between single- and multiple-trait systems.

The effect on quantitative credentials might figure in the Powell analysis in a different manner, however. If anything, Powell places inore einphasis on the "fixed quota" aspect of the Davis system than on its failure to consider more traits. ${ }^{47}$ One inight argue that any system which "insulate[s] each category of applicants with certain desired qualifications from competition with all other apphicants" 48 cannot be said to promote the goal of educational diversity in the most efficient way. Under a quota systein, admissions officers are not free to consider the tradeoff between the nonquantitative factors such as race, age, and geographic background and the quantitative factors designed to measure knowledge and aptitude. The increinent added to the educational environment by a person's familiarity with black culture (or rural background, or presumed greater inaturity due to age) should be discounted to soine extent, so the arguinent goes, by the person's comparative deficiencies in the traditional academic skills. It is, of course, impossible to determine in any precise or scientific manner just when this discounted increinent ceases to exceed the increment promised by the marginal regular applicant. But to say that the tradeoff cannot be computed exactly is not to say that there is no tradeoff at all, or that there is no gain in rationality when a system permits the tradeoff to be considered by means of an admittedly crude formula such as a fixed add-on (e.g., all persons possessing the special traits will have 100 points addcd to their MCAT scores) or by means of intuitive judgments in marginal cases. A fixed quota system, however, means that the final slots in the special admissions prograin are filled without regard to whether the tradeoff between special traits and traditional skills is salutary in terms of the overriding goal of enriching the educational environment. Under strict scrutiny, this sort of indifference to the end that would justify the disfavored means (here, race-conscious decisionmaking) is fatal.

47. $98 \mathrm{~S}$. Ct. at 2762.

48. Id. 
It might be maintained, nevertheless, that a fixed quota is indeed a highly rational means of maximizing educational diversity. One argument in support of such a clain builds from the empirical proposition that most persons are less likely to be productive, interactive participants in the educational process when they are perceived by others or perceive themselves as tokens or in soune other way feel isolated or beleaguered in the environment. Thus, if fifteen students were admitted under a special program and only the ten with the highest quantitative credentials were thought to present a salutary tradeoff of special traits for traditional skills, it might still be highly productive of the goal of educational diversity (which is, after all, an aggregate phenoinenon) to admit the last five if their presence would alter the environment sufficiently for the other ten to affect in a meaningful way their contribution to the "robust exchange of ideas." Of course, at some poimt these last five admittees could be so deficient im traditional academic skills that the net effect of their presence on the educational environment would be negative, but a faculty could reasonably conclude that that point is not reached until the apphicants fall below some fixed minimum level of qualifications. So if the employnent of a fixed quota can be considered an efficient way to avoid the counterproductive phenomenon of tokenism, such a quota might be deemed consistent with the requirement that an admissions program be strictly rational in terms of the goal of educational diversity.

Can a fixed quota be considered to be efficient in this regard? At this point, it may be necessary to differentiate on the basis of numbers and percentages. If the objective is to avoid the dynamics of tokenism, it would seem to be much easier to justify, say, a $5 \%$ quota than one of $15 \%$. Ten percent strikes my intuitive sense of degree as close but ultimately unjustifiable in terms of the avoidance-of-tokenism rationale, at least in large student bodies. (The larger the class, the lower the percentage needed to give special admittees enough numbers to form supportive subcommunities, one major factor relevant to educational productivity).

More fundamentally, is there any more efficient means of avoiding the educationally counterproductive effects of tokenism than the use of a fixed minimun1 quota in the $5 \%$ to $10 \%$ range? No such means occurs to ine. No doubt many gestures might be made in an effort to inake the environment supportive for special admittees: perhaps altering the curriculum to take into account their priorities, providing unusual counseling and other services (such as placement) tailored to their needs, or making certain that the system of formal recognition for outstanding achievement measures not ouly the traditional academic skills but also the kinds of contributions that special admittees are im the best position to make. Moreover, the choice among applicants for special admission 
might be made with weight given to demonstrated ability to perform under conditions of tokenism. Still, there is likely to be no completely adequate substitute for numbers.

Even if the subgoal of avoiding tokenism is best pursued with a quota, however, one must ask whether that subgoal is necessarily to prevail over other subgoals relevant to educational diversity such as that of maximizing the traditional quantitative credentials of the student body. It is not as though a special admissions program can make no contribution to the educational environment unless the special admittees are present in sufficient numbers to form a critical mass. That would be true only if the implausible proposition could be established that when the percentage of persons possessing the favored trait falls below a certain figure (say, 5\%), the few students who possess the trait, and whose likely contribution is lower than it might be due to their isolation, can make no greater contribution to the environment than rival marginal applicants with only quantitative credentials. Again, some consideration of the tradeoff is necessary. Given a certam pool of trait-possessing applicants, some of whom when viewed solely as individuals might have less to offer the educational environment than their rivals with only quantitative credentials but who have the extra "credential" of beimg able im the aggregate to bolster the perforinance of some other special admittees (who would in any event have enough to offer as individuals to justify their adınission), when does the inarginal trait-possessing apphicant have less to offer than the rival applicant with only quantitative credentials, even when this extra bolstering credential is added to the calculus? Only a system which compares the credentials of all applicants can claim to take into account this tradeoff, and in that respect to meet the standard of strict rationality.

Of course, it might be rational im the strict sense to conclude that this "bolstering" credential should have little weight if it means only the difference between $1 \%$ and $2 \%$ trait-possessors in the class (they will all suffer from isolation in any event), should be given great weight in the $4 \%$ to $8 \%$ range, and should count progressively less at higher percentages. If this type of variable weighting systein were employed, however, the ultimate judgment would still be a function of the quahty of applications in a given year froun both trait-possessors and all other applicants, and in that respect would take into account the tradeoff between quantitative and nonquantitative credentials. A fixed quota system, in contrast, does not allow for even a crude consideration of this tradeoff.

The sensitivity to numbers represented by such a variable weightmg system may well be what Justice Powell had in mind when he quoted with approval this passage from the Harvard stateinent of undergraduate adinissions policy: 
[W] hen making its decisions, the Committee on Admissions is aware that there is some relationship between numbers and achieving the benefits to be derived from a diverse student body, and between numbers and providing a reasonable environment for those students admitted. But that awareness does not mean that the Committee sets a minimum number of blacks or of people from west of the Mississippi who are to be admitted. It means only that im choosing annong thousands of applicants who are not only "admissible" academically but have other strong qualities, the Committee, with a number of criteria in mind, pays some attention to distribution among many types and categories of students. ${ }^{49}$

In any event, an admissions policy that gives weight to numbers in this flexible fashion could be considered to be pursuing the goal of educational diversity in a strictly rational inanner, while a system that einploys a fixed quota, even at a very low level and only to avoid tokemsm, might plausibly be tliouglit not to satisfy the requirement of strict rationality.

There is a second respect, distimct from the need for some consideration of the quantitative-nonquantitative tradeoff, in which the demand for strict rationality might lead one to accept the distinctions embraced by Justice Powell. One problem with consideration of only one nonquantitative trait in a special admissions program is that other traits may be at least as closely related to the ultimate goal of educational enrichment through diversity. While it is true that reform normally may proceed "one step at a time" same genus need be attacked simultancously-soine priority judgments related to governmental problem solving can be so distorted as to offend the standard of strict rationality. If, for example, virtually all observers would say that the educational environment of professional schools suffers more due to the shortage of blacks than due to the paucity of accomphished athletes, it would be a departure from strict rationality for a medical school to pursue the goal of educational diversity by treating athletic ability as the only nonquantitative credential to be accorded weight in the admissions decision. Perhaps, although this is much more doubtful, strict rationality slould even be interpreted to prohibit the consideration of any factor witlout simultaneously considering all other factors that are of coinparable relevance to the posited goal (here, educational diversity). Under either of these versions of the strict rationahity standard, one could argue that race (or, inore broadly, ethmic background) simply cannot be viewed as distinctive enough to warrant special treatment as the only nonquantitative trait in the admissions calculus.

49. Id. at 2766

50. Katzenbach v. Morgan, 384 U.S. 641, 657 (1966). See also, Fiss, Groups and the Equal Protection Clause, 5 Philosophy \& PuB. AFF. 107, 115 (1976). 
A major difficulty with this line of rationalization for the Powell opinion is that ethnic background was not the only nonquantitative trait considered by the Davis medical school's admissions process. In fact, it appears that had the eighty-four places in the Davis class that were open to all applicants been filled purely on the basis of quantitative indicators, Bakke would have been admitted. He lost out in the competition for those places precisely because the school gave substantial weight to certam subjective factors that were assessed in a personal interview, and his faculty interviewer found him "rather limited in his approach" and with "very definite opinions which were based inore on his personal viewpoints than upon a study of the total problem." 51 So the Davis program really was, in an important sense, inultitrait. Furthermore, even the competition for the sixteen reserved places was restricted on the basis of three traits, not one: race, disadvantaged educational background, and relative economic deprivation. ${ }^{52}$ If the Davis systein was a departure from strict rationahty because of the way it considered race in comparison with other factors relevant to the goal of diversity, the reason must be that race was given excessive prominence or weight, not that race was the only nonquantitative factor taken into account.

In fact, this conclusion would be warranted even if the Davis prograin liad considered only race in addition to the traditional quantitative criteria. For if the departure from strict rationality is in failing to give comparable considerations their due, it would seem to matter little whetlier a program considers only three factors when four are equally relevant (or the ignored consideration ranks higher on a scale of relevance than soine of the factors that are considered) or takes only one factor into account when at least two are relevant. The failing is in ignoring or being insufficiently attentive to relevant factors, not in leaving the program with only one nonquantitative consideration.

In this regard, moreover, it is significant once again that Justice

51. In 1973, Bakke's interviewer found him "a very desirable applicant." He was denied adinission that year, despite quautitative scores above the average of the students admitted under the regular standards, prinarily because he applied late in the year at a time when only extraordinary nonminority applicants were admitted. In 1974, Bakke applied on time, but drew a different interviewer who formed a mucl more negative opinion of lim. It is notewortlyy (and in faet did not escape Justice Powell's notice) that Bakke's 1974 interviewer was the cliairman of the admissions committee to whoin Bakke liad written the previous year to protest the special admissions prograin. $98 \mathrm{~S}$. Ct. at 2741.

52. As Justice Powell described the system, "[n]o formal definition of 'disadvantage' was ever produced . . . but the chairman of the special committee screened each application to see whether it reflected economic or educational deprivation." In making this judgment, "[t]he ehairman normally clrecked to see if, among other things, the applicant had been granted a waiver of the school's application fee, which required a means test; whether the applicant had worked during college or interrupted his education to support himself or his family; and whether the applicant was a member of a minority group." $98 \mathrm{~S}$. Ct. at 2740. 
Powell emphasizes not the number of traits considered by Davis (although he mentions that aspect) but rather the absence of "competitive consideration." One might say that it is a departure from strict rationality both to exclude from formal, mechanistic consideration certain traits at least as relevant to the goal of diversity as those that are considered in such a formal manner, and also to consider any traits in such a way that they are never evaluated competitively with all the other qualifications relevant to the goal of diversity that might be presented by rival applicants. Either way, there is no assurance that the admissions decisions will reflect priorities that are rational in terms of the posited goal.

Can it be said that some nonquantitative factors are so comparable to race in their relationship to the goal of educational diversity that a failure to accord them the same favored treatment given race (i.e., formal, mechanistic consideration in the admissions decision) amounts to a departure from strict rationality? Bakke, for example, was older than most medical school apphicants, and he had an interesting employment background in the aerospace industry. Was it irrational for the Davis medical school not to accord these traits the same prominence as race if the only legitnnate basis for considering race at all is to promote the goal of educational diversity?

I think it is difficult to maintain that there is any one trait that compares with race im terms of the likely contribution of persons who possess the trait to the goal of diversifying, in an educationally meaningful way, the type of student body that results from primary reliance on the traditional quantitative indicators. It is arguable that other traits such as sex, socioeconomic background, age, undergraduate field of study, and geographic background might matter as much if the typical professional school student body, or the range of personal contacts of its members, were as homogeneous in terms of these traits as it would be in terms of race in the absence of a special admissions program. But among the several traits that seem most important in determining a person's likely role in an educational environment-mainly because they are especially good proxies for certain attitudes, affinities, interests, and experiences (and perhaps even aptitudes) relevant to the learning process-race is distimctive in one respect: members of minority races add an important element that would otherwise be almost totally missing, and that is not the case for applicants who are women, Southerners, in their thirties, or poor.

One might argue, on the other hand, that if race is relevant to educational diversity solely as a proxy for other characteristics that are directly relevant to the learning process, a lack of racial diversity need not mean a lack of diversity with respect to the primary characteristics. For the primary characteristics might show up adventitiously in a class 
of majority-race applicants admitted exclusively on the basis of knowledge and aptitude, or the characteristics might be selected for directly or by means of other proxies. To sustaim the argument that race can rationally be viewed as a uniquely important trait in terms of the diversity goal, one must make a plausible claim that the attitudes, affinities, imterests, and experiences for which race is a proxy are both important in the learning process and difficult to select for either directly or by means of other proxies. Is such a claim plausible?

I believe that membership im a mimority race can be viewed as a good proxy for several personal characteristics that may be important im the learning process. Compared to his white counterpart, a black applicant is much more likely to: (1) have been the object of racial prejudice in a wide variety of contexts, and thus have firsthand knowledge about the nature and impact of such prejudice; (2) have had his aspirations seriously influenced by perceptions regarding what opportunities were available to persons of his race, and thus have a special appreciation of the social significance of aspiration and self-esteem; (3) have had personal relationships with people who are very poor and frequently unemployed; (4) have spent a great deal of time coming to grips with his own racial identity as well as thinking and talking about the social problem of race relations; (5) have been the object of special scrutimy by others who were curious to see how a person of his race would behave or perform in the particular situation, and thus have an appreciation of the "fishbowl" phenomenon in social relations; (6) feel a responsibility to help mitigate the suffering of the persons who have been most oppressed by social and political patterns that can be traced in part to racial prejudice; (7) display a special imterest im and knowledge about the black experience in the United States and the rest of the world; and (8) feel a disenchantment with, if not hostility toward, social structures and institutions (including primciples of distribution) that historically have operated to the detriment of black people. These are characteristics for which the trait of membership in a minority race is a good proxy. They are, moreover, characteristics which are not likely to be possessed in combination by many persons who would be selected in a highly competitive admissions process solely on the basis of quantitative credentials. There is no reason to suppose that other proxies such as low socioeconomic status or experience growing up in a ghetto are more closely correlated with the sum of these characteristics. Nor is it likely that these primary characteristics could be directly selected for in the admissions process without unacceptable expense and risk of error or fraud, not to mention the symbolic and constitutional difficulties involved im directly selectimg for those characteristics that relate to political and social attitudes. Thus, the fact that race is relevant to 
educational diversity only as a proxy for other characteristics is no reason to minimize the importance of racial diversity in a student body.

I conclude that most educational institutions can quite rightly regard racial homogeneity as by far the greatest threat to the goal of a truly diverse educational environment, and hence cannot be said to depart from the standard of strict rationality when they accord race a prominence in their admissions decisions far greater than that accorded any other nonquantitative trait. ${ }^{53}$ In attempting to rationalize Justice Powell's opinion, therefore, one should attribute no significance, so far as the value of strict rationality is concerned, to the fact that in the Davis prograin race was given greater weight than any other nonquantitative factor, or that race was considered in a nore formal, mechanistic fashion.

This is not to say, however, that there was no departure from strict rationality in the Davis inedical school's failure to give any weight to certain other traits that might be relevant to educational diversity. Again, the concept of "competitive consideration" may hold the key to appreciating the view of strict rationality that informs the Powell opinion. For while it may be rational to single out race formally as a trait to be given a fixed and significant weight in the admissions process, it may be irrational, in terms of the ultimate goal of diversity, to give no weight to certain other factors that are relevant to the goal in the same way that race is, i.e. as proxies for attitudes, affinities, interests, and experiences that would enrich the educational process. In this view, race cannot be treated as an incommensurable factor in the equation: the saine theory that makes race relevant also makes relevant other traits that serve as proxies for educationally enriching characteristics. If race is the most significant trait in this respect because it is the best proxy for certain educationally enriching characteristics, its prominence is only a matter of degree; it would be irrational, a distortion of priorities, to treat the relative significance of race as a difference in kind justifymg complete inattention to other nonquantitative traits that also serve as good proxies for educationally enriching characteristics of comparable scarcity and inportance. Under this line of analysis, a special admissions prograin would fail the test of strict rationality if, in filling places in the class for which minority-race status is treated as a positive credential, the prograin gave absolutely no weight (not simply less weight than is given racial status) to other nonquantitative traits that are relevant to the goal of educational diversity.

Does this aspect of strict rationality explain Justice Powell's invali-

53. Although it is not irrational to treat race as a proxy for other educationally-relevant characteristics, there are other reasons to view the use of race as a proxy as costly. These are well described in Posner, The DeFunis Case and the Constitutionality of Preferential Treatment of Racial Minorities, 1974 SuP. CT. REv. 1, 7-15. 
dation of the Davis program? It must be remembered that under the Davis system unspecified factors were considered by means of the subjectively scored personal interview. This was the stage of the process that actually doomed Bakke's application. However, under the system employed by the inedical school a majority-race applicant who possessed one or more of these other diversity-promoting traits still could not compete for the sixteen places in the class that were reserved for minority-race students. Even if one assumes that no other trait or combination of traits constitutes as good a proxy for educationally enriching characteristics as does the trait of mmority-race status, the failure to give other traits any weight in the competition for the sixteen reserved places might be considered irrational because of the additional relevant factor of the standard quantitative credentials. For if race is different from other diversity-proinoting nonquantitative traits only as a matter of degree, and if a person's relative competence in the skills that are ineasured by the standard quantitative indicators affects his abihty to draw upon his special background in an educationally productive way, it would be a departure from strict rationahity for an admissions prograin invariably to prefer the applicant with the superior nonquantitative trait (race) over rivals who have vastly superior quantitative credentials in addition to relevant nonquantitative traits. And that preference is exactly what is dictated by a racial quota.

So far, we have discovered two ways in which an admissions prograin that einploys a fixed racial quota might be said to offend the standard of strict rationality insofar as the compelling goal of educational diversity is concerned. First, suclı a program does not take sufficient account of the tradeoff that inevitably occurs whenever an applicant witl superior quantitative credentials is displaced by an applicant who presents superior nonquantitative credentials. The tradeoff can reach a point where the net effect of preferring the nonquantitative credentials is negative in terms of the ultimate goal of a robust, stimulating educational environment, and a system that employs a fixed quota is too inflexible to respond when that turning point is reached. Second, a quota systein that considers only the trait of race fails to give proper weight to other nonquantitative traits whose relevance to the goal of educational diversity is establishcd by the same line of reasoning that makes race relevant; even if race can plausibly be regarded as more important in this respect than any other single trait (or even any combination of traits), it would be a departure from strict rationality to give these other traits no weight whatsoever in the admissions calculus.

In addition, there is at least one other way in which an admissions program that relies on a racial quota might be considered not to pursue the goal of educational diversity in a strictly rational inanner. One might argue that the very notion of educational diversity is based on an 
ideal of creative, vibrant, subtle, and unique interaction that cannot be promoted by such crude devices as quotas, or even fixed add-on formulas or more flexible methods of weighing factors determined in advance to be relevant. The only way to pursue the goal of educational diversity in a strictly rational fashion, according to this argument, is to give persons who have a good understanding of the process of academic interchange a great deal of discretion, at least at the margm, to make mtuitive admissions judgments that are constrained as little as possible by abstract formulas or predeterminations. Perhaps the Harvard undergraduate admissions system can be viewed as such a process.

I do not think that this line of rationalization for the Powell opinion can withstand analysis, at least in the strong version just described. Admittedly, educational diversity is a complicated, perhaps indefinable goal that can be meaningfully pursued only by sophisticated means. But it would amount to a complete rejection (not just appropriate subordination) of the value of efficiency to hold that a decisionmaking process cannot possibly exhibit the requisite sophistication if any element of the process employs, no matter how carefully, the kinds of simplifymg generalizations that are inevitable when large nuinbers of decisions must be made with finite resources of time and personnel. Moreover, there is every indication in the Powell opinion that educational diversity is not to be viewed as an ideal that is fully crystallized and refined in the constitutional scheme but rather as a concept that different imstitutions may properly define in different ways. Surely there are some variants of the diversity ideal for which certain traits such as race or sex (or an understanding of ancient civilizations) would always be relevant and always be worth at least so many plus poimts, at least until the base makeup of the entering class that would be produced if only the quantitative measures were considered were to alter so radically as to make these traits no longer in short supply. So the Powell opinion should not be taken to mean that only a program that eschews all formal treatment of nonquantitative factors can pass the test of strict rationality.

There exists, however, a weaker version of the argument that cannot be dismissed so easily. Suppose it is granted that some factors might rationally be given a fixed weight or at least treated as always relevant. Cannot one still maintain that the complicated nature of the diversity ideal requires that the door always be left open for unanticipated or previously unvalued factors to be considercd in the decisionmaking process? This version of the argument is different from the argument developed above regarding the failure to consider nonquantitative traits other than race in filling the places set aside for special admittees. For that argument rested on the proposition that there is a departure from strict rationality in refusing to compare two applicants 
with theoretically commensurable traits, both of which might be evaluated in a mechanistic manner or at least determmed in advance to be relevant. Under the argument presently being considered, im contrast, the irrationality is in presuming to identify im advance and/or to assign fixed weights to all the factors that might enrich the educational environment.

I believe a good case can be made for the proposition that an admissions program which considers only nonquantitative factors that are specified im advance cannot be said to pursue the goal of educational diversity im a strictly rational fashion. For if the goal is indeed a broadening of horizons and a creative tension in mteraction rather than the representation of certain groups as a matter of distributive justice, there is no rcason to believe that the goal is most likely to be achieved by ineans of a predetermined formula. Witl regard to many characteristics, it may be admitted, the pool of applicants to most schools is not likely to change inucl from year to year so that there is likely to be no significant gain to be had in decisionmaking efficacy by adjusting admissions criteria to reflect clianges im the applicant pool. However, with regard to the nonquantitative traits that contribute most to such phenomena as the broadenimg of horizons and the generation of intellectual tension, the pool of applicants is likely to vary signifiantly from year to year. This observation holds, I believe, both with regard to the isolated appearance of unusual traits (e.g., nrany years spent as a missionary im the Third World), and also with regard to the concentration of more common diversity-promoting traits (e.g., the number of applicants from the mountain states or from working class families). And if there is such variation, it would be a departure from strict rationality not to take into account the distinctive features of each pool of apphcants in determining which quahties will be given special weight in the effort to produce the optimal class diversity.

Of course, a fixed formula for evaluating admission credentials has the virtues which inhere im any device that limits the discretion of decisionmakers. Particularly when there is no strong consensus concerning which criteria are most relevant-a function, im part, of the fact that the goal of educational diversity is itself nnprecise-there is good reason to fear that discretionary judgments will reflect the prejudices of the imdividual decisionmakers more than any coherent imstitutional policy. Would it not be rational in the strict sense for a faculty to place a higher premium on controlling discretion in the special admissions process than on achieving maximum sensitivity to vicissitudes im the pool of applicants? Perhaps so, but in light of the availability of other strategies for controlling discretion (e.g., decision by committee or a process of review), one might plausibly mamtam that it would be a departure from strict rationahty for an admissions policy to employ any 
formula for evaluatimg nonquantitative diversity-promoting traits that is not responsive to the distinctive features of each year's pool of applicants. ${ }^{54}$ One who held this view would require, at a minimum, that a special admissions program be sufficiently flexible to give meaningful consideration both to unanticipated traits that are relevant to the goal of educational diversity and also to familiar traits that might be in short supply in soine years even if not in most.

It might be argued, however, that this feature of flexibility, while relevant in the abstract to the rational pursuit of educational diversity, cannot be at the base of Justice Powell's analysis because the Davis prograin itself was flexible in the appropriate sense. It will be remembered that the program gave considerable weight to personal qualities, assessed by means of a subjectively scored interview, whose relevance and weight were not determined in advance.

There are two problems with this response. First, one might question whether a procedure by which each applicant is subjectively evaluated for general character by one of several interviewers really serves the goal of educational diversity rather than other goals such as maximizing the integrity or diligence of the student body. Second, and more important, under the Davis system many apphicants who had quantitative credentials higher than those of some of the special admittees were not even eligible to have a personal interview because their quantitative scores placed these applicants below the cutoff line for regular admission. ${ }^{55}$ How, one might ask, can the medical school claim to have been seeking true diversity when it refused even to consider the nonquantitative credentials of this large pool of applicants who were "qualified," in terms of the school's own standards as applied to minority-race applicants, to undertake the curriculum?

To this second objection, a defender of the Davis program might respond that it is rational to have a lower quantitative cutoff for minority-race applicants than for applicants who possess other relevant nonquantitative traits because no other single trait or combination of traits signals as great a likely contribution to educational diversity, and hence represents as much of a credential to add to the applicant's quantitative credentials, as does the trait of minority-race status. But even if the empirical proposition on which this response relies is plausible as a general matter, there is no reason to suppose that the proposition will

54. Admittedly, majorities on committees and reviewing panels can have their own biases as well, but so too can the people who construct the fixed formulas. While formulas are not without efficacy in controlling collective, representative bias, it is primarily the special problem of individual, unrepresentative bias that justifies according a high value to the control of discretion, and that problem ordimarily can be checked at least as effectively by bringing more people into the decision as by insisting that an individual decisionmaker adhere to a formula.

55. $98 \mathrm{~S}$. Ct. at $2740-42$. 
hold true in every admissions year no matter what shifts occur in the profile of the applicant pool or what unusual individual applications are received. And if not, then a program cannot be said to pursue the goal of educational diversity in a strictly rational fashion if it does not retain enouglı flexibility to let any "qualified" applicant who so desires make a case that he will contribute at least as much to educational diversity as will the applicants who possess the nonquantitative traits that have been determined in advance to be worth some weight in the admissions decision. Given the enormous administrative cost, it would probably be asking too mucl in the name of rationality to require an admissions system to employ a sensitive scanning procedure to pick out sucl unanticipated or undervalued nonquantitative credentials. That all applicants, however, have at least some opportunity to make a case for their admission in terms of diversity, even if only in a blank space on the admissions form, would seem to be a minimum requirement for any program that is to be judged strictly rational in its pursuit of educational diversity. The Davis medical sclool's admissions process did not grant this opportunity to all qualified applicants, nor would any fixed quota system of the sort disapproved by Justice Powell. Only when sucl an opportunity is granted, one might conclude, can an adınissions program be regarded as, in Justice Powell's words, "flexible enough to consider all pertinent elements of diversity in light of the particular qualifications of eacl applicant, and to place them on the same footing for consideration, although not necessarily according them the same weight." 56

There are, then, three elements of strict rationality which might plausibly be thought to be absent in any special admissions prograin that employs a fixed racial quota: (1) some consideration, however imprecise, of the tradeoff between quantitative and nonquantitative credentials; (2) a method of evaluatimg nonquantitative traits which treats them as commensurable on the ground that they are all proxies for comparable educationally enriching characteristics; and (3) a capacity to consider relevant traits that might not be anticipated or properly evaluated before they are presented in actual applications. The distinctions drawn by Justice Powell in his Bakke opinion have some validity when viewed in light of these three elements of rationality. This fact alone suggests that the value of strict rationality-the closeness of the relationship between the means of race-conscious decisionmaking and the end of educational diversity-provides at least one of the keys to an understanding of the Powell standard. And if so, officials designing or ruling upon other special admissions programs should pay particular attention to the three elements of rationality enumerated above.

56. Id. at 2763 . 


\section{B. Individual Dignity}

As discussed at the beginning of this section, strict rationality is not the only value that inight rationalize the distinctions einbraced by Justice Powell. The values of individual dignity and the reduction of racial prejudice throughout the society might also explain how one could view the Davis program as different from Harvard's, and how one inight draw a constitutional line between special adinissions prograins that employ racial quotas and those that do not. In fact, on first reading Justice Powell appears to rely mainly on the proposition that the race-conscious programs of which he disapproves might be thought to injure in a unique and unacceptable way the individual inajorityrace applicants who are displaced by thein. ${ }^{57}$ Is this value of individual digmity a different, and perhaps more important, key to understanding the Powell standard?

At the outset of this part of the analysis, it is important to note that there is a crucial difference between, on the one hand, utilizing the notion of individual dignity (and of requisite injury thereto) in order to establish a prima facie case of constitutional violation sufficient to trigger strict scrutiny and, on the other hand, utilizing the notion of individual dignity as the ultimate basis for concluding that the law or program at issue cannot survive strict scrutiny and hence must be declared unconstitutional. In all likelihood, the element that triggered strict scrutiny in Powell's view of the case was the injury done to Bakke's dignity as an individual when he was disadvantaged because of his race in his quest for a place in the Davis inedical school class. ${ }^{58}$ But all race-conscious decisionmaking processes do this much injury (and thus must be tested under the demanding standard of strict scrutiny). The nore interestimg interpretative question regarding the Powell standard is whether the second, and ultimate, phase of the analysis-when the particular race-conscious prograin is held either to pass the test of strict scrutiny or not-is much concerned with this value of individual dignity. On this point, the language of the Powell opinion is not decisive. ${ }^{59}$ Again, the question is best answered by determining

57. See, e.g., id. at 2763 n.52.

58. Justice Powell's emphasis at this threshold stage of his analysis on the phenomenon of individual injury can be discerned from the following passage: "When [political judgments] touch upon an individual's race or ethnic background, he is entitled to a judicial determination that the burden he is asked to bear on that basis is precisely tailored to serve a compelling governmental interest. The Constitution guarantees that right to every person regardless of his background." Id. at 2753.

59. At the ultimate stage of his opinion, when he measures the Davis program against the standard of strict scrutiny, Justice Powell refers several times to the claim of the majority-race applicant to be treated as an individual. For example, Powell praises the Harvard special admissions program on the ground that "[t]his kind of program treats each applicant as an imdividual in the admissions process." Id. at 2763 . Also, Powell seems to have been influenced by a notion of an individual right to compete. He criticizes the Davis program because under its provisions "[n]o 
whether a plausible case can be made for distinguishing between the Davis and Harvard programs, and between racial quotas and "competitive consideration," on the basis of their differential effects on the dignity of the displaced majority-race apphicants.

In a recent article, ${ }^{60}$ Ronald Dworkin argues that no such case can be inade. He distinguishes between a flexible system of the sort approved by Powell in which being a inember of the Caucasian race may be "a constant small handicap in the competition for all the places" in a class, and a quota system of the sort disapproved by Powell in which being Caucasian is "no handicap at all in the coinpetition for a slightly sinaller number of places" but rather amounts to a "partial exclusion" because certain places in the class are placed completely out of the reach of all white applicants. Dworkin asserts that in terms of the value of individual dignity, there is no important difference between a handicap and a partial exclusion, and particularly that Powell's notion of "competitive consideration" of all relevant credentials cannot distinguish these two types of race-conscious decisionmaking in this respect:

Whether an applicant competes for all or only part of the places, the privilege of calling attention to other qualifications does not in any degree lessen the burden of his handicap, or the unfairness of that handicap, if it is unfair at all. If the handicap does not violate his rights in a flexible plan, a partial exclusion does not violate his rights under a quota. The handicap and the partial exclusion are only different means of enforcing the same fundamental classifications. In principle, they affeet a white applicant in exactly the same way-by reducing his overall chances-and neither is, in any important sense, more individualized than the other. ${ }^{61}$

And since the injury is solely in the reduction of the candidate's probability of getting admitted, there is no reason to assume that a quota system is, im the abstract, more injurious to the displaced inajority-race applicant than a flexible race-conscious system:

His fate depends on how much either the handicap or the exclusion reduces his overall chances of success; and there is no reason to assume, a priori, that the one will have a greater or lesser impact than the other. That will depend on the details of the plan-the degree of handicap or the proportion of exclusion-not which type of plan it is. ${ }^{62}$

matter how strong their qualifications, quantitative and extracurricular, including their own potential for contribution to educational diversity, [majority-race applicants] are never afforded the chance to compete with applicants from the preferred groups for the special adinission seats." $I d$. at 2764. On the other hand, Powell never develops his notion of individual dignity, and several times refers to the poimt that the failure to provide for competitive consideration of all applications is counterproductive to true educational diversity, a social rather than individual concern. See, e.g., id. at 2761, 2763.

60. Dworkin, The Bakke Decision: Did It Decide Anything?, New YoRK Review of Books, Aug. 17, 1978, at 20.

61. Id. at 23.

62. Id. 
Surely Dworkin has a point if indeed the only way that race-conscious admissions programs can be said to injure, in the constitutional sense, the individual apphicants who are displaced is in reducing their chances of success. One might attempt to refute Dworkin, however, by identifying other sources of injury to the individual digmity of these displaced applicants.

One possible source of injury is the special affront to their dignity that people feel when they are rejected by an objectively irrational decisionmaking process. This happens to most of us in our varied efforts to hve in this highly bureaucratized civilization, and the experience engenders in many of us a particularly intense feeling of upset that might be worthy of constitutional concern. If, in fact, no important social goal was advanced by the Davis medical school's decision to admit some minority applicants in preference to Bakke, he would be entitled to be outraged, and to consider his dignity diminished, by that decision.

This source of injury is not, however, very promising for one who would refute Dworkin, because the injury is completely parasitic on the judgment that the decisionmaking process at issue is irrational. If that is so, the value of individual dignity adds nothing to the constitutional calculus: the value of strict rationahty would already provide a sufficient ground to invalidate the prograin. Indeed, assuming that strict scrutiny is already triggered, the value of strict rationality is likely to prove niore helpful to a constitutional challenger because it entails that all programs be invalidated which do not serve important social goals in a strictly rational fashion, whereas in order to establish an imjury to dignity stemming from irrationality one inust show not only that the program does not rationally serve its goals but also that because of its irrationahity the prograin denies the rejected applicant a benefit to which he had a preexisting moral or legal claim; the difficult notions of "desert" and "entitleinent" form a necessary part of the dignity analysis. So I conclude that the individual injury that is caused when people are disadvantaged by irrational decisions should not be considered a distinctive part of the rationalization for Justice Powell's position.

A second source of individual injury might be in the harm to dignity that occurs when people are disadvantaged because of criteria over which they have no control. Bakke might claim, for example, that a program such as a quota system which treats race as an incommensurable credential deprives him of control over his fate in a way that a flexible program which permits the racial factor to be cancelled out by acquired traits does not. The problem with this argument, however, is that analytical aptitude is a trait that figures prominently in virtually all admissions systems, and it also is a trait over which applicants have no real control. Of course, many admissions processes, including that run 
by the Davis medical school, permit this trait of analytical aptitude to be "cancelled out" by nonquantitative credentials assessed during a personal interview, but only for students who have passed a high (in terms of the overall pool of apphicants) threshold of analytical aptitude. Moreover, it is likely that many admissions programs employ a "fixed quota" for analytical aptitude im the sense that a certam number of places in the class are reserved, formally or imformally, for applicants who have superior analytical aptitude without regard to how these persons measure up in terms of nonquantitative considerations.

This analogy to the more-or-less immutable trait of analytical aptitude suggests that most persons do not regard it as an affront to their dignity when they are excluded from consideration for some places im the class because they lack certam extraordmary natural abilities. If membership in a mmority race does mdeed make a person more "able" in certain respects relevant to the educational process-and this is a premise that is established when a race-conscious program passes the test of strict rationahty with regard to the goal of educational diversity-there is no reason to deny that trait a preemptive role in the selection of part of the class simply because rival applicants cannot help the fact that they do not possess the trait.

A third possible mjury to dignity occurs when a person believes that he has lost out in an important decisionmaking process because he was not treated as a complete person but rather was evaluated in a distorted fashion on the basis of a few artificially extracted and arbitrarily assessed credentials. This grievance is one of the central problems of the individual-state relationship im our time. Bakke might argue that even if it is rational from the perspective of an efficiency expert to process apphications to medical school on the basis of a few specified traits such as undergraduate grade-point average, aptitude test score, race, and geographic background, a decent respect for individual dignity requires that the process examme more closely each applicant's total file and make decisions, at least at the margm, on the basis of a rounded assessment of the individual attributes of each competing applicant. "If you are to rejcct me," Bakke inight say to the admissions committee, "at least you should have the decency to look ine straight im the file."

This point certainly has sone appeal, but its implications extend far beyond the problem presented by race-conscious decisionmaking. Applicants are routinely rejected because their grade point averages are lower than those of their rivals when no (or inadequate) adjustment is made for the quality of the respective schools at which the grades were earned, the difficulty (or lower grading curves) of the courses that were taken, or the trends of grade performance exhibited by the competing applicants, all undeniably relevant considerations if past grades are 
treated as predictors of future performance. Similarly, aptitude test scores often are compared directly as predictors of future performance when a more sophisticated prediction could probably be achieved by considering the degree to which an apphicant's earher aptitude scores predicted his performance at previous stages of his education. In short, every admissions process overlooks many variables of undoubted relevance, even when attention is confined to the quantitative, performance-predictive measures. When nonquantitative credentials are also taken into account, oversimphification becomes even more inevitable. For example, if geographic background is deemed relevant, an admissions committee cannot be expected to assess each applicant's lifetime odyssey. Some simple (and possibly distorted) measures must be adopted, such as the residence of parents, the location of the high school from which the applicant graduated, or the place where the applicant has resided the longest in the last five years.

There is an important dilemma here. People care a lot about whether they are admitted to the schools of their choice, and they expect admissions decisions to be made as fairly as is humanly possible. Yet many schools have to process such vast quantities of applications for admission that the bureaucratic impulse toward formulization and other shortcuts tends to dominate. Probably, fewer resources are devoted to the process of making admissions decisions than would be dictated by a perfect market ineasure of what most applicants would be willing to pay for. But even if these resources were greatly expanded, an applicant's expectation to be "treated as a complete person" in the admissions process could never be realized. Inevitably, apphicants for admission inust be treated as partial persons, as repositories of formal credentials. Insofar as applicants claim a right to be treated as coinplete persons in the way defendants charged with capital crimes and child-custody contestants should be, the only sensible response of the constitutional systein is to reject the claim and hopefully thereby to lower the expectations.

I conclude, therefore, that both the Davis and Harvard admissions systems, as well as virtually all other systems whether characterized by quotas or "competitive consideration," fall so far short of treating applicants as complete persons that any differences in this respect between various systems cannot be of constitutional significance. One must look elsewhere than to this aspect of individual dignity im order to formulate a convincing rationale for the distinctions drawn by Justice Powell.

A fourth way in which the value of individual dignity might explain the difference between racial quotas and more flexible race-conscious programs relates to the concept of participation. For most people, it is particularly hurtful to be totally excluded from an activity, 
to have absolutely no hope of participating. When certain places in an entering class are reserved exclusively for persons with a specified trait, persons without the trait are totally shut out from participation in the competition for those places. This arrangement might be thought to diminish their dignity inore than would an arrangement in which they had some chance, however small and however reduced by their nonpossession of the trait, of securing the desired place. It hurts to have no hope.

I do not think this line of rationalization succeeds. First, all admissions programs hold out no hope whatever to inany would-be applicants - those who fall below the minimum cutoff with regard to quantitative credentials. More importantly, there is no reason to regard each single place in the class as the appropriate unit for measuring the phenomenon of participation. If some places were unique-if, for example, financial aid or priority in admittance to seminars were linked to certain places - an applicant who was totally excluded from the competition for any of these places might have a grievance in terms of individual dignity. But when places in the class are fungible, as they are in inost admissions programs, surely the appropriate unit with respect to which such inatters as participation and hope should be measured is the class as a whole. And if this proposition is accepted, Professor Dworkin's point holds that a quota systein is not necessarily less favorable to applicants who do not possess the favored nonquantitative traits than is a inore flexible trait-conscious system: "That will depend on the details of the plan - the degree of handicap or the proportion of exclusion-not which type of plan it is."

Finally, an applicant might feel that his dignity has been diminished if he was rejected to inake rooin for a competing applicant who is less qualified in an overall sense but who is thought by the admissions committee to deserve special help because of past injustices visited upon him. "Why," the rejected applicant might ask, "must I be the person who pays for the past wrongs of society?" Race-conscious admissions prograins might differ in the degree to which they embody this "lielping hand" or "reparations" sentiment, or at least in the degree to which they are generally perceived to do so. Perhaps Justice Powell's aversion to racial quota systeins stems ultimately from the intuition that in filling the final slots without inaking particularistic judgments, these systeins treat the majority-race applicants who are inarginally rejected as pawns to be sacrificed in the quest for expiation. There is an allusion to this view at the point in the opinion when Powell argues that the desire to redress past social wrongs is not a compelling state interest:

[T]he purpose of helping certain groups whoin the faculty of the Davis Medical School perceived as victins of "societal discrimination" does 
not justify a classification that imposes disadvantages upon persons like respondent, who bear no responsibility for whatever harm the beneficiaries of the special admissions program are thought to have suffered. ${ }^{63}$

This concern for the "innocent" victim of a reparations policy miglit also have influenced Justice Powell later in his analysis when he drew a line between the Davis and Harvard programs, and between racial quotas and other kinds of race-conscious systems.

Here again, one possible objection to this line of rationalization is that it adds nothing to the analysis that builds on the value of strict rationality. If, in fact, a particular race-conscious program can be said to serve the goal of educational diversity in a strictly rational fashion, persons who are denied admission under the program liave no grounds to feel that they were treated as pawns or were otherwise used to atone for society's sms - these applicants were rejected because they were less qualified, in the fullest sense, than the persons who displaced them. On the other liand, if the program cannot be said to pursue the goal of diversity in a strictly rational manner, the program can be invalidated on that basis witlout liaving to complicate the calculus by bringing in the subtle factor of individual dignity.

Of course, it is possible, at least in theory, to imagine a prograin that was designed and mamtained for the purpose of redressing past social wrongs, and which treated as necessary pawns in the process those applicants who were disadvantaged by the special criteria adopted, but whicl miglit nonetheless pass the test of strict rationality in relation to the legitimate goal of educational diversity. Applicants rejected under sucl a program miglit justifiably feel an affront to their dignity even thougli they would have no sucl grievance had the identical program been instituted witls only the goal of educational diversity in mind, for in that case they would not have been treated as pawns. The chances are shin, lowever, that a program actually designed for reparations purposes would serve the goal of educational diversity in a strictly rational fashion. Moreover, a faculty motivated by the desire to redress past wrongs to blacks is also likely to view the presence of blacks in the student body as valuable from a purely educational point of view. If the justification for a race-conscious admissions program were shifted in midstream in order to satisfy constitutional standards, at some point wouldn't the rejectcd applicant's dignity-based grievance dissipate? These considerations, as well as the practical problem of determining what motivations lie behind particular programs, lead me to believe that a rationalization of the Powell opimion should accord no distimctive sigmificance to the fact that applicants miglit feel an affront

63. $98 \mathrm{~S}$. Ct. at 2759. 
to their dignity when they are denied an educational opportunity not on the basis of comparative credentials broadly viewed but rather to make room for less-qualified victims of past social wrongs.

I can think of no other important ways in which the types of raceconscious programs distinguished by Justice Powell can be thought to reflect differences in the dignity with which rejected applicants are treated. I conclude, therefore, contrary to the common assumption, that the value of individual dignity is not an essential element in a rationalization of the Powell opimion. In seeking out the fine hine of legahty, faculties who design, and judges who rule upon, other raceconscious admissions programs should not regard the effect on the dignity of rejected applicants as an important aspect of the governing standard that emerges froin the Bakke decision.

\section{The Reduction of Racial Prejudice}

In addition to the values of strict rationality and individual dignity, the value of reducing the incidence of racial prejudice throughout the society might serve to rationalize the distinctions drawn by Justice Powell. Not only might the resentinents and stigmas engendered by race-conscious admissions programs justify subjecting all such programs to strict scrutmy, those resentinents and stigmas might serve as a basis for distinguishing between different types of race-conscious decisionmaking in reaching the ultimiate judginents as to which programs survive strict scrutiny.

It is true that Justice Powell makes no attempt to defend his distimctions im terms of this value of reducing the general incidence of racial prejudice. At the conclusion of the crucial section of his opinion in which he delineates his constitutional standard, however, Powell places a curious emphasis on cosmetics in explaining why the Davis program should not be upheld:

It has been suggested that an admissions program which considers race only as one factor is simply a subtle and more sophisticated-but no less effective-means of according racial preference than the Davis program. A facial imtent to discriminate, however, is evident im petitioner's preference program and not demed in this case. No such facial infirmity exists in an admissions program where race or ethnic background is simply one element - to be weighed fairly against other elements-in the selection process. ${ }^{64}$

There next follows a passage that might be read as a judicial promise to look the other way so long as educational imstitutions do not flaunt their racial preferences and thereby trigger the feared resentınents and stiginas:

[A] Court would not assume that a university, professing to employ a

64. Id. at 2763. 
facially nondiscriminatory admissions policy, would operate it as a cover for the functional equivalent of a quota system. In short, good faith would be presumed in the absence of a showing to the contrary in the manner permitted by our cases. ${ }^{65}$

Perhaps Powell is saying that appearances are what matter most because the critical value is the longrun diminution of racial prejudice throughout the society and, depending on how they are perceived by the public, different race-conscious programs may have quite different effects on the racial attitudes of the populace.

There are several respects in which a racial quota might be thought to engender or reinforce the general phenomenon of racial prejudice. For one thing, such a formal, rigid aspect of an admissions systein tends to draw attention to itself, and often to blow out of proportion in people's minds the role the trait of race actually plays in the process. That soine people, particularly Jews, have an almost instinctive aversion to quotas because they were once used for quite different and deeply offensive purposes only exacerbates this phenomenon of overemphasis. If rejected applicants feel an affront to their digmity because they "never had a chance" to compete for certain places im the class, resentments are bound to be engendered that could easily spill over into racist attitudes. That none of the angry rejected applicants could survive a debate witll Ronald Dworkin regarding the inherent unfairness of quotas is beside the point. All of these considerations assume added force when race is the only factor on which the quota is based, for then the people who possess this one trait may be singled out as convemient scapegoats for the inyriad discontents and frustrations that are caused by any selective admissions process.

In addition to the resentments engendered thereby, a system that employs a racial quota might be counterproductive to the goal of reducing racial prejudice because such a system can stigmatize its beneficiaries in certam ways. For example, if there has been no "competitive consideration" for the final positions in the class, minority-race students who are admitted might be perceived by some teachers and fellow students as inere bodies that were needed to fill slots rather than as persons with positive qualifications. And this stigmatization will not be confined to those minority-race students who really were at the inargin and who might not liave been admitted under a flexible race-conscious process; all minority-race students will in some degree be stigmatized. In addition, when race is the only nonquantitative trait taken into account, even if done so in a flexible manner, the deviation froin a purely quantitative measure of qualifications which the consideration of race represents stands out as aberrational. The dominant value system of 
the institution, its symbolic statement of what kinds of students it really wants, is not altered. A faculty's decision to weigh several nonquantitative credentials, on the other hand, is likely to have the effect of syinbolically impeaching the traditional quantitative ineasures, at least as sole determinants of the quality of a student body. Students who are deviant in terms of the dominant value system of their institution are bound to view theinselves, and be viewed by others, as somehow inferior.

If, then, the value of reducing racial prejudice in the society at large can be thought to support the distinctions loosely delineated by Justice Powell, should this value be considered a vital element in any rationalization of the Powell standard? I think there are at least two good reasons why this conclusion should be rejected. First, I believe it is almost always a bad thing for constitutional standards to be based on the purported perceptions of the populace regarding what is fair or rational rather than on well-considered and explicitly defended arguments respecting fairness and rationality. It is too easy to manufacture a "general behef" or a "widespread feelimg." My speculations about how racial quotas might engender or reinforce racist attitudes are plausible, but they are only speculations. They are not, I think, very good building blocks for constitutional analysis.

Second, if admissions prograins are to be evaluated not on the basis of what they really entail but instead in terms of how they are generally perceived, educational institutions can only regard the constitutional standard as a legitimation of subterfuge and hypocrisy. I know that soine defenders of racial preferences beheve that subterfuge is the proper policy at this stage of society's grappling with the problem of racial discrimination. I disagree. In this context, subterfuge necessarily entails hypocrisy, and to my mind hypocrisy inevitably is a corrupting phenomenon. I beheve, for exainple, that many educators who lie or equivocate to the public about the quantitative qualifications of their minority-race students wind up undervaluing these students in their own minds, as well as underestimating the good sense and trust of which the public is capable when it is dealt with in a straightforward inamier. Were I an admissions officer or a lower court judge, I would strive mightily to avoid any interpretation of Bakke that would give controlling weight to the cosmetic aspects of special admissions prograins.

These views about the impropriety of resting constitutional judgments on judicially perceived public perceptions and about the dangers of subterfuge are, however, rather personal in nature. There is nothing in our constitutional tradition, nor in the language of Justice Powell's 
opinion, ${ }^{66}$ which compels decisionmakers to accept these views in interpreting the Bakke precedent. Therefore, since a case can be made for Justice Powell's distinctions based on the likely effects of different prograins on general attitudes about race, an admissions officer or judge inight properly interpret the Powell opinion to rest in whole or $\mathrm{m}$ part on the value of reducing the incidence of racial prejudice in the society at large.

Such a conclusion would have some different implications than the conclusion that the value of strict rationahity is the main basis for the Powell standard. For example, under a theory based on strict rationality, it would not matter whether race was the only trait given formal or mechanistic consideration so long as other colnmensurable traits were taken into account in some fashion. But if general public perceptions (and their hkely effects on racial attitudes) are the key, the singling out of race as the only nonquantitative factor to be considered formally or mechanistically would count strongly against the legality of a particular special admissions program. Conversely, a well-disguised "quota" in the form of an informal "goal" which produced slight variations in the percentage of special admittees from year to year might pass muster under the public perceptions rationale but not under the strict rationality theory (unless the yearly variations could be shown to reflect a rational calculation of the tradeoff between quantitative and nonquantitative credentials). Also, whether an adınissions process was "flexible" in the sense that applicants with relatively low quantitative credentials (below the normal cutoff for regular admittees) were permitted to "make a case" based on unique ability to contribute to educational diversity would seem to matter much more under the strict rationality theory than under the public perceptions theory.

I have no doubt, for the reasons outlined above, that if I were interpreting Bakke in an official capacity (as I may have to as a voting member of a law faculty), I would imterpret Justice Powell's opinion to be based exclusively on the value of strict rationality. I would evaluate specific race-conscious admissions programs in terms of how rationally they were related to the ultimate goal of educational diversity. But since other decisionmakers might properly ascribe to the pivotal Powell opinion a quite different rationale - one based either exclusively on the value of reducing the mcidence of racist attitudes or on soine blend of this value and the strict rationality value-a complete analysis of the Bakke precedent must necessarily address the imphcations for various types of special adınissions programs of both rationales.

66. See, e.g., id. at 2763 n.53. 


\section{IMPLICATIONS FOR VARIOUS TYPES OF RACE-CONSCIOUS ADMISSIONS PROGRAMS}

In hight of the interpretations developed above of the Stevens and Powell opinions, a number of conclusions can be drawn regarding what general types of race-conscious admissions programs should be upheld under the Bakke precedent.

First, it is clear that an admissions process that is not covered by Title VI because it is not part of a "program or activity receiving federal financial assistance" is not governed by the Court's holding in Bakke. It is conceivable, of course, that the five justices who reached the constitutional issue in Bakke might agree in some future case that certain types of race-conscious programs are unconstitutional and hence unlawful even apart from Title VI. However, the four justices in this category who joined the Brennan opinion directed their attention mainly to the Davis program, which they regarded as constitutional by a wide margin, and thus did not indicate with sufficient particularity to control future adjudication exactly where they would draw the constitutional line. So Bakke should not be read to establish any constitutional restrictions on the consideration of race in the admissions process.

For programs that are covered by Title VI, the Powell opinion embodies the controlling legal standard. The significance of Bakke as a precedent thus turns on what the Powell standard, with its alternative or supplementary rationales based on the values of strict rationality and the reduction of racial prejudice generally, is thought to imply for the various types of race-conscious admissions programs that might be adopted by educational institutions that receive federal financial assistance.

One type of program, which has several variants, is the one mentioned above which identifies a number of traits (e.g., age, race, socioeconomic background, geographic background, sex, and undergraduate enuphasis) for special consideration. One version of such a program would select students solely on the basis of grade-predictive quantitative measures with the proviso that at least $10 \%$ of each entering class must be older than twenty-eight, at least $10 \%$ must be black or Clicano, at least $10 \%$ must be from families which fall below a certam socioeconomic measure, at least $10 \%$ must be from west of the Mississippi River, and so forth. Thus, if there were 100 places in the class, the ten applicants with the highest quantitative scores of all the applicants older than twenty-eight would be sure to be admitted, and others im the over-twenty-eight group could compete for the forty nonquota slots. Moreover, if one apphicant helped fill more than one quota (say, a 
thirty-year old, poor, black, female, classics major from California), the number of remaining "nonquota" slots would imcrease proportionately (in the example given, the woman's admission would free up five nonquota places). It is noteworthy that this system could produce a class consisting of the top ninety or inore applicants in ternus of quantitative credentials, plus however many minority-race students were needed to fill the $10 \%$ quota; this profile would occur if the other quotas were filled, as might well happen, adventitiously from the ninety apphicants with the highest quantitative credentials. Would this admissions prograin pass muster under Powell's standard?

I think not. The program would fail to provide for any consideration of the tradeoff, in terms of the likely benefit for educational diversity, between quantitative and nonquantitative credentials because the quota in each category would be filled without regard to the comparative quantitative credentials of the applicants eligible for special admission and those in the general pool. Moreover, since the applicants eligible for special admission would compete agaimst each other only within their own categories, the program would not treat the relevant nonquantitative traits as comnensurable. Finally, the program would not leave the door open for applicants to present and have considered other traits that are relevant to the goal of diversity in the same manner as the six traits enumerated $\mathrm{m}$ advance. Under the standard of strict rationality, these shortcomings would be fatal.

The question is closer if one adopts the "public perceptions" rationale for the Powell opinion. The program would not single out race as the only relevant nonquantitative factor; disappointed apphicants might vent their frustrations against westerners or persons over age twenty-eight as well as against blacks and Chicanos. Still, the rigid quota aspect would be deeply resented, and if it turned out in practice (as it inight) that many more blacks and Chicanos were helped by the quota system than persons with the other traits (or if the disparity in terms of quantitative credentials was much greater for the beneficiaries of the race quota tlian of, say, the Western quota), the plan could give rise to serious racial animosities. I conclude that under eitluer rationale for the Powell standard, this hypothesized program should be considered unlawful in light of Bakke.

Suppose, however, that a program were devised which gave formal consideration to the six factors enumerated above, but provided for flexible goals rather than quotas for eacl category. The program might specify, for example, that apphicants whose admission would increase the percentage of women, blacks, westerners, etc. sliall be given so many plus points until the percentage in their category reaches a given figure (say, 15\%). So in a given year it might help a borderline applicant a lot to be from California, but in other years this trait would 
count for nothing because the quantitative measures alone would have produced a class with at least $15 \%$ westerners.

Personally, I would hold such a program invalid under Bakke because it would fail the test of strict rationality in one (but only one) respect: by not giving apphicants the opportunity to have considered nonquantitative traits relevant to diversity other than those specified in advance. I believe, however, that one who adopts the public perceptions rationale for the Powell standard should uphold this program: it would not single out race for special attention, and it would probably not engender the resentments or the stigmas that quota systems do. This judgment holds, I believe, even if only two traits-race and one other-are considered, although the case gets easier the greater the number of traits that are given formal consideration.

A inultifactor program, even one witls a fixed scale of plus points up to a fixed percentage of representation of each trait, would pass muster under iny reading of the Powell opinion (and, a fortiori, under the public perceptions rationale) if the program provided for a category of miscellaneous diversity-promoting traits. Thus, if there were, say, six categories of specified traits plus an open-ended category for other applicants with unusual backgrounds, I think the program would be sufficiently flexible to qualify as highly rational. This would be true even if the plus points for miscellaneous diversity were awarded only up to a smaller percentage of representation (say, 5\%) than were true for the specified traits, for it would be rational to conclude that tokenisin is not a factor (or, in any event, is unavoidable) for truly unusual traits, and that only so much "spice" of the sort represented by these unpredictable traits is optimal given the tradeoff in terms of the skills measured by the quantitative indicators. Similarly, I see no reason why strict rationality should require that all specified traits be valued the same, either in terms of the number of plus points added or the percentage of representation beyond which plus points are no longer added. So long as there is always some consideration of the tradeoff between quantitative and nonquantitative credentials-so that, for exanple, a westerner who is slightly below the line for admission on quantitative credentials alone might prevail over a black who is far below that line-the system would seem to be rational even if it values some traits more than others, for some traits are more likely than others to contribute to the quahity of the educational environment. That traits must be treated as commensurable does not mean that they must be treated as equivalent.

So far, we have considered only programs which give formal consideration to nore than one trait. Can any special admissions program which gives formal weight only to race be upheld under the Powell standard? What, for example, is the legal status after Bakke of the 
common type of race-conscious admissions program in which race is the only factor given formal consideration and the percentage of minority-race students in the class varies within a small range (say, between $10 \%$ and $15 \%$ ) from year to year, depending on the quantitative qualifications of the ininority-race students who apply and the number of accepted ininority-race applicants who choose to attend?

This type of prograin should not be thought to comport with the Powell standard. The prograin would take proper account of the quantitative-nonquantitative tradeoff only if the percentage of minority-race students admitted were a function both of the quantitative credentials of the mimority-race applicants and those of the majority-race applicants. To be rational in the strict sense, a program needs to be flexible enough to be able to respond to the phenomenon of an unusually strong group of majority-race applicants. ${ }^{67}$ Apart froin this tradeoff consideration, the single-factor, flexible-goal program is irrational in its failure to consider in any fashion other nonquantitative traits, specified and unspecified, that are relevant to the goal of educational diversity in the same manner as race is relevant, even if not in the saine degree. Thus, one who adopts the strict rationality justiflcation for the Powell standard should judge such a program to be in violation of Title VI.

Under the public perceptions rationale for the Powell standard, the program might be regarded as impermissibly counterproductive in its effect on racial attitudes simply because of the way it singles out race as the sole nonquantitative factor to be considered. This is a close question, however. For it might be argued that the feared racial stigmas and resentments will only ensue with sufficient frequency and intensity when the public perceives that mimority-race applicants are being treated as a favored class apart, the beneficiaries of "the functional equivalent of a quota system." 68 Of course, even if this is the appropriate test, it is not clear how the program under consideration should be evaluated. For if the number of mimority-race admittees is a function solely of the quality of the pool of ininority-race applicants, one can say that the minority-race applicants are placed in a class by themselves in that they have only to compete against an absolute standard established largely, if not exclusively, by previous minority-race applicants. Would this fact alone be perceived by key segments of the

67. Of course, since the pool of inajority-race applicants is much larger than the pool of minority-race applicants, the law of averages suggests that there will be greater variation from year to year in the credentials of the minority-race applicants. So even under a program that does make the constitution of the class turn on the quantitative credentials of both groups of apphicants, the quantitative profile of the minority-race applicants is likely in practice to be the more significant variable. This does not mean, however, that there can be no such thing as an unusually strong year for majority-race applicants, and when that occurs it is important that the admissions program be able to respond to the phenomenon.

68. See 98 S. Ct. at 2763. 
general public as a special cause for resentment or negative stereotyping? I do not know. If I had to guess, I would say that the untutored public probably would not be sensitive to the distinction, which is highly significant in terms of rationality, between programs that make the percentage of minority-race admittees a function solely of the credentials of the minority-race applicants and programs that make the percentage a function of the credentials presented by all applicants. On the other hand, I suspect that serious resentments and stigmas ensue whenever race is singled out as the only nonquantitative consideration to be taken into account.

The difficulty I experience in trying to answer these questions only convinces me further that the public perceptions rationale ought to be abandoned. This basic objection is without significance, however, for the prograin presently being considered, because I conclude that under either the strict rationality or the public perceptions rationale for the Powell standard, the Bakke decision should be read to disallow any special admissions prograin covered by Title VI which benefits only members of minority races and which makes the percentage of special admittees turn solely on the quahity of the credentials presented by minority-race applicants.

What if race were treated as the only relevant nonquantitative trait but were considered in the admissions calculus by means of a fixed add-on-i.e., every minority-race applicant has a fixed number of points (say, 150) added to his aptitude test score and also a fixed number (say, 1.0) added to his grade point average? Suppose further that the amount of the add-on were computed with the goal in mind of producing, on the average, a certain percentage of minority-race students in the class. This system could be defended as embodying sufficient consideration of the quantitative-nonquantitative tradeoff, for even if the special admissions program were designed to achieve over a broad span of time certain numerical goals relating to racial representation, tliose goals would not be ends in themselves. If in any given year, or even over the long run, the school received fewer outstanding minority-race applications than anticipated, or more outstanding majority-race applications, the result would be fewer minority-race admittees than originally was anticipated; the controlling consideration would still be academic quality rather than racial proportionality. The system would fail the test of strict rationality, however, by closing off all consideration of other nonquantitative factors relevant to the goal of diversity. Moreover, I think this fixed add-on approach is even more vuhierable under the public perceptions rationale than the system just considered, despite the fact that the fixed add-on is more equitable. Under the public perceptions rationale, what matters most is appearances, and a scale that gave minority-race students a set of extra points 
would probably be viewed on the public as a precise measure of the degree to which these students really are inferior.

As one who would read the Powell opinion as based exclusively on the strict rationahty value, I would attach no significance to such a mistaken public perception, and thus would uphold a fixed add-on system if it also provided for the taking into account of other relevant nonquantitative traits that inight be presented by inajority-race applicants. It would not be sufficient, however, if an admissions program did this in the common fashion simply by tipping the scales in borderline cases. The possibility would have to remain open, at least in theory, for a majority-race applicant with remarkable credentials in terms of the diversity goal to liave the benefit of an add-on just as large as that routinely given minority-race applicants. Only then would the second condition of strict rationality, that all the relevant nonquantitative traits be treated as truly commensurable, be satisfied. ${ }^{69}$ This would mean that all qualified applicants, not simply those above a fairly high cutoff im terms of quantitative credentials or those high on the waiting list, would be entitled to have their potential contributions to educational diversity assessed, if only by having their essays on this subject read carefully by soineone who regularly plays an important role in admissions decisions (the director of admissions or a faculty or student member of the admissions committee, but not a file clerk). No doubt this requirement would add somewhit to the lieavy burdens already borne by many admissions offices. But sliort of this kind of serious consideration of the nonquantitative credentials of all qualified applicants, I see no way that an add-on system of the sort described above can be justified under any theory that makes sense of the distinctions that lie at the heart of Justice Powell's pivotal opimion in Bakke.

\section{CONCLUSION}

Mr. Justice Powell does have a theory. It is a theory which requires that admissions programs treat mmority-race applicants as persons who have soniething valuable to contribute to the educational environment rather than as persons who need special help. What this aspect of Justice Powell's analysis implies about the nieanimg of Bakke as a precedent depends a great deal on one's view of precedent. Under the view of precedent that I hold, ${ }^{70}$ the Bakke decision should operate as a significant constraimt on lower-court judges who would like to uphold, and administrators who would like to adopt, special admissions progranis that are tailored to serve predominantly compensatory or redistributive objectives. In contrast, the Bakke precedent should pose little difficulty for those special admissions programs that are founded

69. See pp. 41-46, 50 supra.

70. See notes $6 \& 13$ supra. 
on the premise that, because of their skills and special backgrounds, certain minority-race apphicants represent a valuable resource which an educational institution primarily concerned with the quality of its dialogue ought to draw upon. That some of us would have preferred that Justice Powell had concluded that race-conscious decisionmaking also can be einployed to serve compensatory or redistributive ends does not mean that we can disiniss his pivotal opinion as incoherent and hence not a source of meaningful standards to which lower courts and administrators need adhere. 